\title{
Evolución de un lugar sagrado en el Istmo de Tehuantepec durante la colonia: cruces pictográficas, verae effigies y conjuros satánicos
}

\section{Evolution of a Sacred Place in the Isthmus of Tehuantepec during the Colony: Pictographic Crosses, Verae Effigies and Satanic Spells}

Artículo recibido el 9 de enero de 20I9; devuelto para revisión el 5 de abril de 20I9; aceptado el 3I de enero de 2020; http://dx.doi.org/IO.2220I/iie.I8703062e.2020.II6.2718.

Fernando Berrojalbiz Instituto de Investigaciones Estéticas, unAm. berlanz@hotmail.com; http://orcid.org/oooo-oooI-7544-I669.

Líneas de investigación Arte rupestre y paisaje cultural; arte rupestre zapoteco del Istmo de Tehuantepec, prehispánico y colonial; arte rupestre prehispánico y colonial de Durango, México.

Lines of research Rock Art and Cultural Landscape; Zapotec Rock Art of the Tehuantepec Isthmus, prehispanic and colonial; prehispanic and colonial Rock Art of Durango, México.

Resumen Ba'cuana fue un santuario de suma importancia en el paisaje simbólico que crearon los zapotecas en el Posclásico en la parte sur del Istmo de Tehuantepec, donde destacaban sus expresiones rupestres. En este trabajo se estudian las expresiones que se pintaron después de la llegada de los espańoles. Combinando estudios de estilo, iconográficos y de análisis de pigmentos se logra una separación en dos etapas principales durante la colonia, con características diversas, que dan cuenta de la evolución de este sitio en estos tres siglos. Ba'cuana siguió siendo un santuario muy venerado, centro de un nuevo paisaje sagrado, en el que quedó plasmada la agencia de las poblaciones zapotecas, que desarrollaron sus propios discursos visuales, los cuales eran reflejo de la creación de una nueva cultura fruto de la reapropiación de elementos artísticos y religiosos cristianos, de la ortodoxia y del lado diabólico.

Abstract In the symbolic landscape created by the Zapotecs in the Postclassic period in the southern part of the Isthmus of Tehuantepec, Ba'cuana was a sanctuary of great importance, where their rock paintings were significant. In this paper I study expressions that were painted after 
the arrival of the Spaniards. Combining studies of style, iconography and the analysis of pigments, a division in two main stages during the Colonial period is established, from diverse characteristics that account for the site's evolution during three centuries. Ba'cuana remained a highly venerated sanctuary, center of a new sacred landscape, in which the agency of the Zapotec population was revealed. They developed their own visual discourses. These were a reflection of the creation of a new culture, result of the re appropriation of Christian artistic and religious elements, from orthodoxy and demoniac practice.

Palabras clave Arte rupestre; arte colonial; arte zapoteco; pictografía; arte; verae effigies; arte diabólico.

Keywords Rock Art; Colonial art; Zapotec art; pictography; art verae effigies; diabolical art. 
DOI: https://doi.org/10.22201/iie.18703062e.2020.116.2718

FERNANDO BERROJALBIZ

INSTITUTO DE INVESTIGACIONES ESTÉTICAS, UNAM

\section{Evolución de un lugar sagrado en el Istmo de Tebuantepec durante la colonia: cruces pictográficas, verae effigies y conjuros satánicos}

$\mathrm{E}$ 1 sitio Ba'cuana se encuentra en la zona del istmo correspondiente al estado de Oaxaca (fig. I). Esta región está delimitada por un arco montańoso, correspondiente a las últimas estribaciones de la Sierra Madre del Sur por el oeste, y su unión con la Sierra Atravesada, por el norte. Al interior de dicha región se encuentra la llanura costera. En medio de la misma, al norte de la ciudad de Juchitán de Zaragoza, se eleva un cerro que destaca en todo el paisaje, el Cerro Blanco. No hay otro cerro de estas dimensiones que se eleve en mitad de la llanura. El cerro forma parte del límite entre dos poblaciones, Ciudad Ixtepec (San Jerónimo Ixtepec), hacia el norte, y Santa María Asunción Ixtaltepec, hacia el sur.

En la falda suroeste del Cerro Blanco se encuentra una aglomeración de bloques redondeados de granito de gran tamaño. En mitad de ésta destacan dos bloques, que son los de mayor tamaño y que están próximos entre sí, a una distancia de I4 metros uno del otro (fig. 2). En cada uno de estos bloques existe un conjunto de expresiones rupestres, que se diferencian, en principio, por el lugar que ocupan en la superficie de la roca.

La primera roca con la que se topa uno al llegar al lugar, la peña-cueva, presenta una oquedad en la parte inferior, que forma un espacio bajo la roca semejante a una cueva, la cual tiene cuatro accesos desde el exterior, el más grande en el noroeste del bloque (fig. 3). El espacio interior no permite a una 
DOI: https://doi.org/10.22201/iie.18703062e.2020.116.2718

I74 FERNANDO BERROJALBIZ

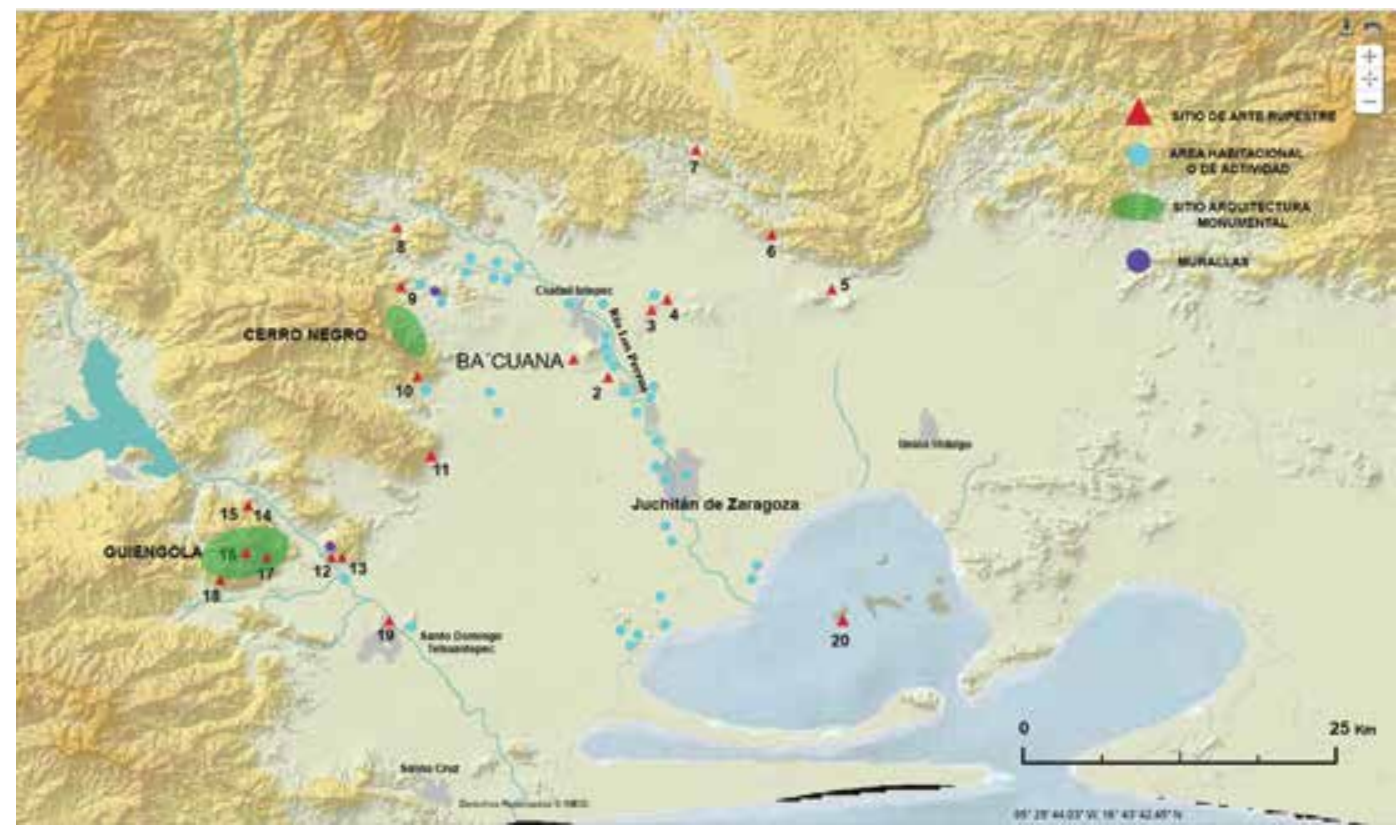

I. Mapa del paisaje cultural creado por los zapotecos en el Posclásico en el Istmo de Tehuantepec. Elaboración: Fernando Berrojalbiz.

persona estar de pie, tiene que estar agachado o tumbado. La altura de este espacio varía, pero en promedio se aproxima a un metro o a un metro y 20 $\mathrm{cm}$. La longitud y la anchura también varían debido a las dimensiones irregulares del lugar, aproximadamente de 8 metros de suroeste a noreste y 5 metros de noroeste a sureste.

En el techo de este espacio interior se encuentran la mayoría de los motivos de este bloque. Además, existen motivos deteriorados en el exterior, concretamente en la cara o pared oeste de la roca y en uno de los frentes de la roca que miran hacia el sur. En estas paredes exteriores son pocos los motivos que se pueden distinguir debido a la erosión.

En el conjunto interior de esta roca la mayor parte de los motivos fueron realizados en época prehispánica, pero también se pueden hallar algunos otros efectuados en diversas etapas de la colonia.

El otro bloque con expresiones rupestres, la peña-parada, se encuentra unos metros hacia el noroeste. En la parte oriente se nota que una porción de la roca se desgajó, desde la mitad de la altura hacia el suelo, dejando dos paredes casi en 


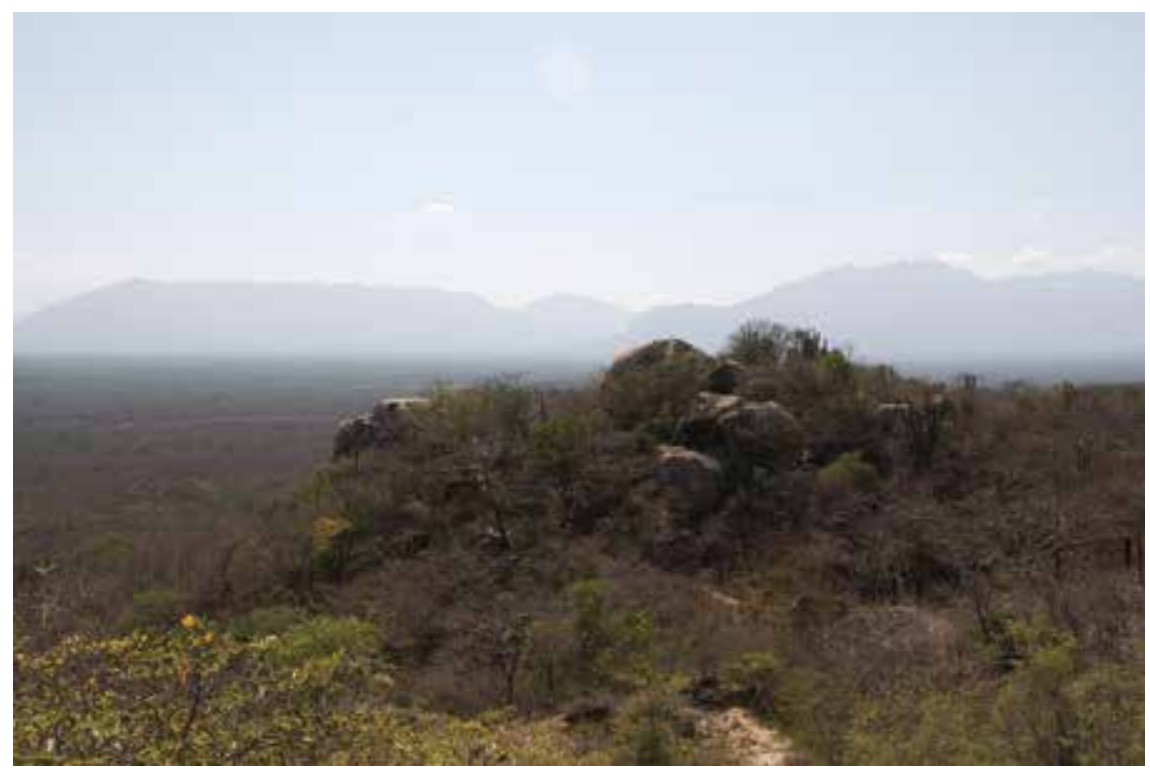

2. Vista del sitio Ba'cuana desde la subida al Cerro Blanco, donde se aprecian los dos grandes bloques con pinturas rupestres. Foto: Fernando Berrojalbiz.

ángulo recto que están remetidas en la roca protegidas por el techo que forma la parte superior remanente. De estas dos paredes o frentes, uno, el de mayores dimensiones, mira hacia el oriente y el otro hacia el sur sureste. En el panel que mira al oriente se halla una serie de motivos realizados en época prehispánica. Sin embargo, en el panel que mira hacia el sur, además de unos pocos motivos prehispánicos, domina un conjunto de elementos pertenecientes a la época colonial. Se puede apreciar que estos últimos fueron plasmados cuidando de afectar o tapar lo menos posible a las expresiones anteriores. Por tanto, en esta roca destaca la convivencia de pinturas prehispánicas y coloniales (fig. 4).

\section{Estudios previos}

Aunque algunos estudiosos visitaron el sitio a finales del siglo $\operatorname{XIX}^{1}$ y se realizaron algunos registros del sitio a principios del siglo $\mathrm{xx}$, no fue sino hasta los

I. Caecilie Seler, Auf alten Wegen in Mexico und Guatemala. Reiseerinnerungen und Eindrücke aus den Jahren 1895-I897, Ernst Vohsen, ed. (Berlín: Dietrich Reimer, 1900). 
DOI: https://doi.org/10.22201/iie.18703062e.2020.116.2718

176

FERNANDO BERROJALBIZ

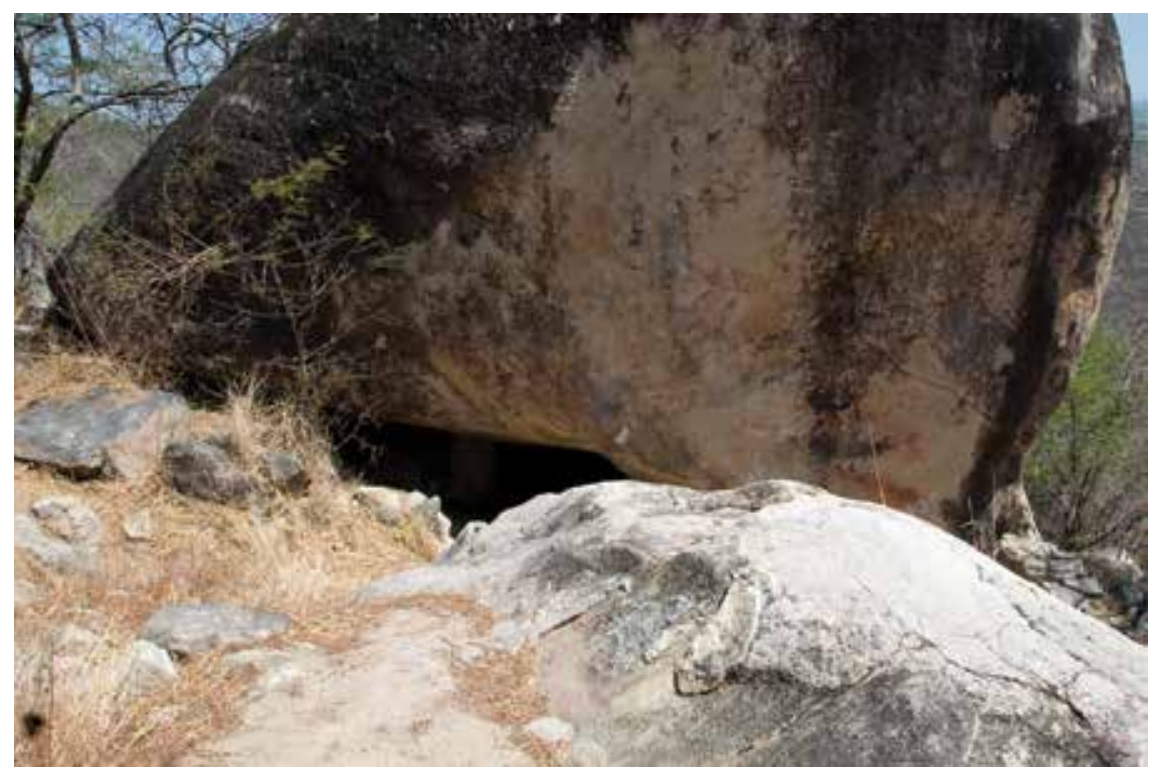

3. Foto de la entrada del espacio interior de peña-cueva del sitio Ba'cuana. Foto: Fernando Berrojalbiz.

años noventa que se hizo un estudio más completo del sitio a cargo del arqueólogo del INAH, Roberto Zárate Morán, ${ }^{2}$ quien logró un primer registro gráfico bastante completo y de gran valor del sitio y atribuyó la autoría a los zapotecos. Sin embargo, fechó las pinturas prehispánicas en el Clásico, con la presencia del sistema numeral de dicho periodo. En trabajos anteriores ${ }^{3}$ expuse mis razones para atribuirles correctamente a la época Posclásica, con la presencia de su propio sistema numeral y la pertenencia de estas pinturas a la tradición es-

2. Roberto Zárate Morán, Un mito de creación zapoteca en las pinturas rupestres de Dani Guiaati (México: Casa del Pueblo de Asunción, Ixtaltepec/Consejo Nacional para la Cultura y las Artes/ Instituto Nacional de Antropología e Historia, 2003).

3. Fernando Berrojalbiz, "La Ba'cuana, Istmo de Tehuantepec: el encuentro de dos tradiciones en un lugar sagrado", en La vitalidad de las voces indigenas: arte rupestre del contacto y en sociedades coloniales, ed. Fernando Berrojalbiz (México: Universidad Nacional Autónoma de México-Instituto de Investigaciones Estéticas, 2015), 329-362; Fernando Berrojalbiz, "Arte rupestre del sur del Istmo de Tehuantepec: ¿¿una variante regional del estilo Mixteca-Puebla?”, en Estilo y región en el arte mesoamericano, coords. Pablo Escalante y Ma. Isabel Álvarez Icaza (México: Universidad Nacional Autónoma de México-Instituto de Investigaciones Estéticas, 20I7), 247-262. 


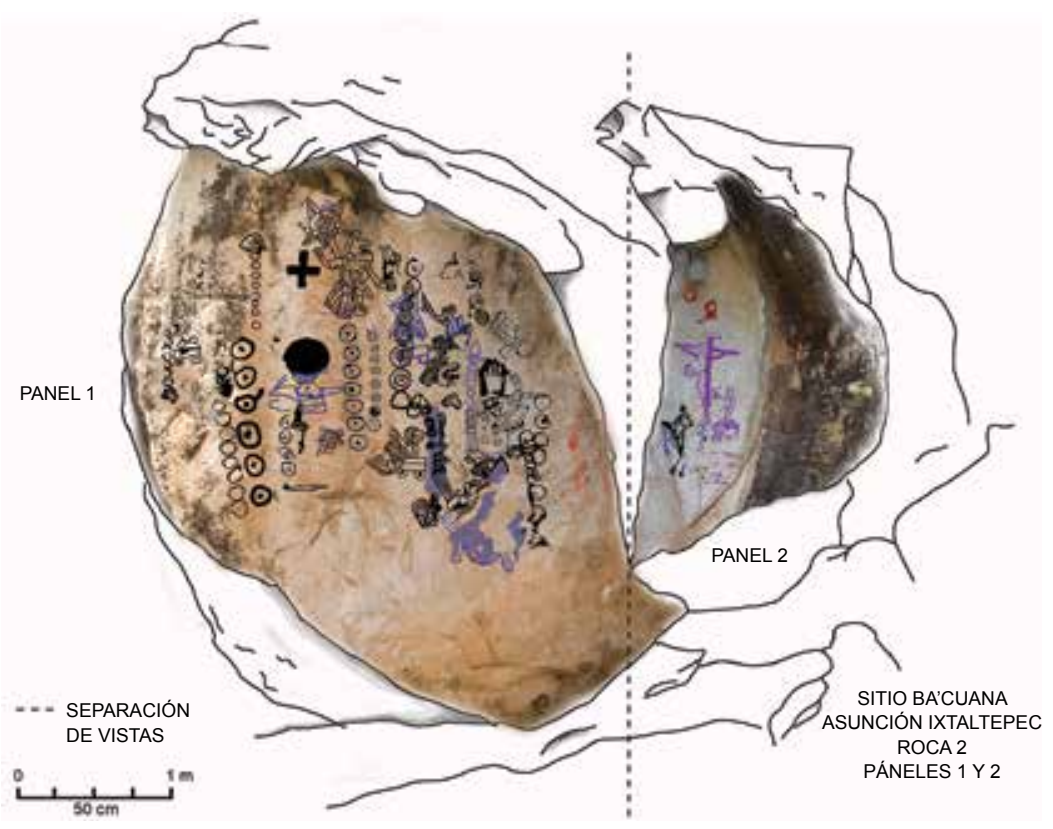

4. Dibujos de los motivos de los dos paneles de la Peña-parada del sitio Ba’cuana. Elaboración: José Moisés Cerero Arellano.

tilística e iconográfica Mixteca-Puebla, pero con variantes locales. De las pinturas coloniales, Zárate hace un análisis breve, tan sólo del Cristo crucificado y de las palabras en alfabeto latino que están debajo.

\section{Caracteristicas de las expresiones prehispánicas}

Los motivos que más abundan (fig. 5) se pueden clasificar en cuatro grupos: I) signos de días del calendario Posclásico, muchas veces asociados a numerales (fig. 6); 2) vasijas cerámicas en forma de cuencos que llevan encima animales o plantas; probablemente representaciones de ofrendas (fig. 7); 3) cabezas de un ser que combina aspectos de diferentes animales, que al compararse con la iconografía Mixteca-Puebla, parecen corresponder a una serpiente fantástica (fig. 8); 4) hileras de círculos, pero que no corresponden a numerales. Destaca también la presencia de al menos tres representaciones de Cocijo, el dios del rayo y de la lluvia zapoteco. 
DOI: https://doi.org/10.22201/iie.18703062e.2020.116.2718

178

FERNANDO BERROJALBIZ

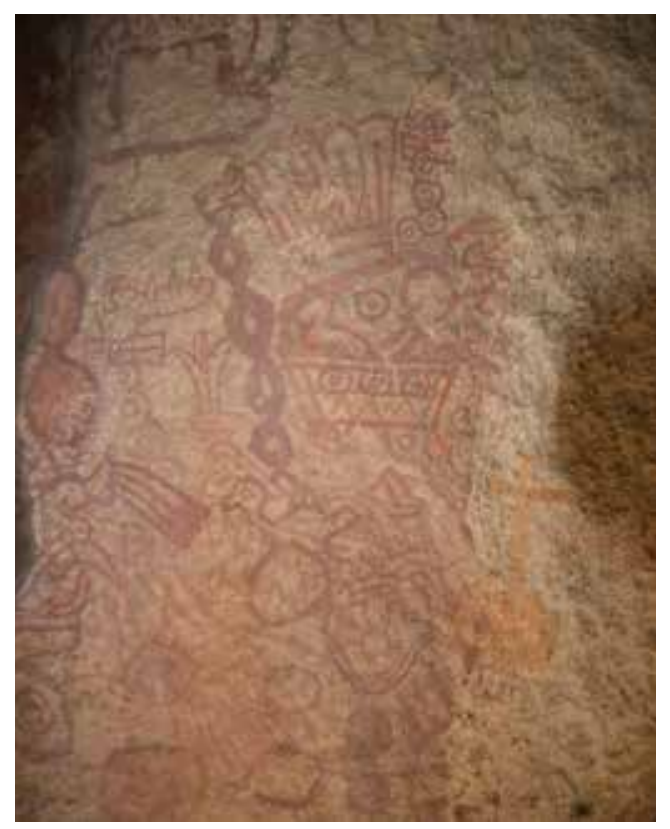

5. Detalle de las pinturas del techo del espacio inferior de la Roca I del sitio Ba’cuana. Foto: Pedro Ángeles.

Los mensajes principales que transmiten las pinturas parecen referirse al culto a la montaña sagrada, que almacena el agua, las semillas y los animales en su interior, y de manera más concreta, peticiones a los dioses y seres que habitan sus entrańas, como serpientes fantásticas de agua y de fuego, y Cocijo, dios del rayo y la lluvia, pero también dios de la tierra. En ese vínculo el agua tiene un protagonismo especial; se pide el agua, las lluvias buenas, pero se intenta aplacar los rayos, el agua excesiva, las inundaciones. También se pide por las buenas cosechas y éxito en la caza. ${ }^{4}$ Se busca una relación armoniosa con la tierra, a la cual se considera una entidad con vida, una especie de monstruo, y con los poderosos seres que la habitan y controlan, convocando y exaltando la fertilidad del mundo, el milagro de la vida. La peña-cueva, y especialmente su espacio inferior, su cueva, era una entrada al inframundo, relacionada con los

4. Esta interpretación de los mensajes que transmiten las imágenes prehispánicas de este sitio coincide con bastante exactitud con la tradición oral recogida por Martínez Gracida a principios del siglo xx sobre el lugar. Manuel Martínez Gracida, Los indios oaxaqueños y sus monumentos arqueológicos, t. II (ms. con láminas) (Oaxaca de Juárez: Biblioteca Pública Central "Margarita Maza de Juárez, s. f.), láms. 3 I y 32. 
6. Dibujo de un signo del calendario posclásico zapoteco asociado a un numeral. Dibujo:

Fernando Berrojalbiz.

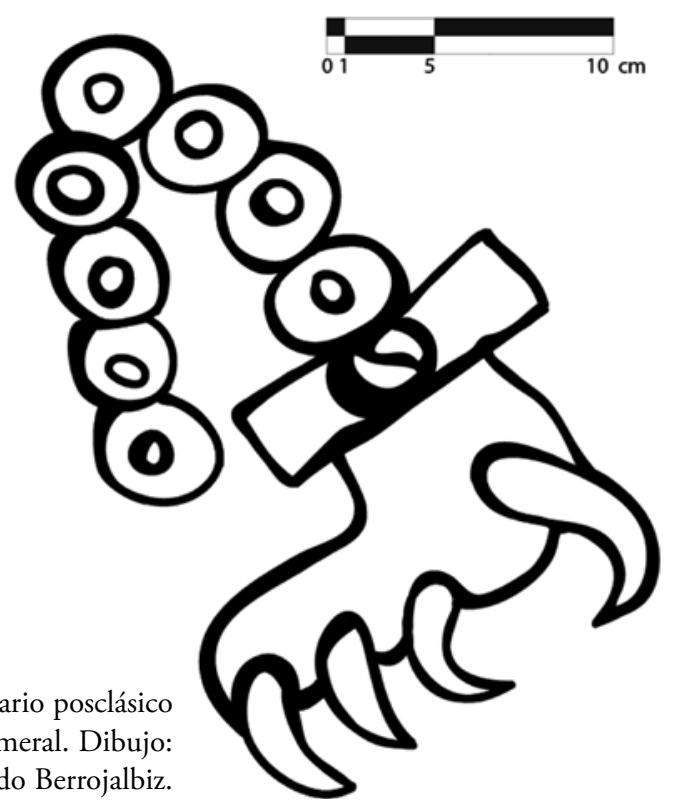

muertos. Además, era una entrada a las entrañas de la montańa, al interior de ese monstruo de la tierra en donde moraban todos esos seres extraordinarios.

Existen muchos casos de superposiciones de imágenes, aunque hasta el momento se observa que todas corresponden al Posclásico y a la tradición Mixteca-Puebla. La aglomeración y la superposición de los motivos indican que no es un único discurso con cierta ordenación, sino que son muchos mensajes pequeños, repetitivos, que no se respetan y se superponen a los anteriores, como las peticiones en un santuario moderno.

Ba'cuana se trata, sin duda, de un gran santuario, un lugar sagrado, situado de manera más o menos equidistante de los asentamientos ubicados en el arco montañoso pero también como punto central de los sitios agrícolas alineados en las riberas del río Los Perros (véase fig. I), todos ellos creados a partir de la llegada de los zapotecos al istmo, un siglo y medio antes de la Conquista, aproximadamente. ${ }^{5}$

5. Estudios etnohistóricos señalan que desde el siglo xIV se produjeron entradas zapotecas al istmo para controlar rutas de comercio. Pero, es a partir del siglo xv cuando se produce una migración al istmo y se conquista esta área. Michel Oudijk y Maarten Jansen, "Tributo y terri- 


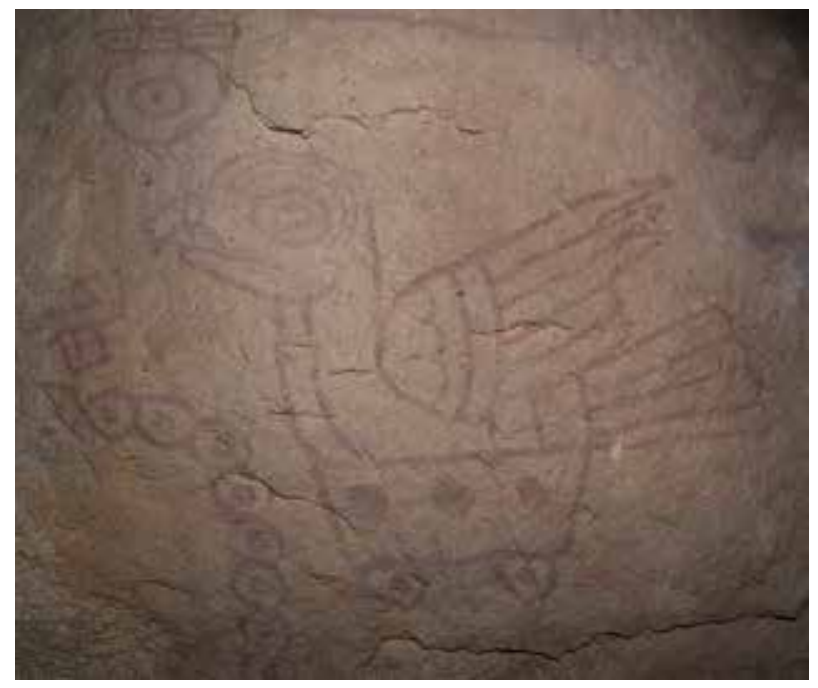

7. Motivo en color rojizo de un recipiente cerámico sobre el que se encuentra un ave, un tipo de loro. En la parte inferior tiene intervenciones coloniales en color naranja. Foto: Ernesto Peńaloza.

Entre las imágenes prehispánicas de las dos rocas, al parecer no hay grandes diferencias en la iconografía, aunque destaca en la peña-parada la presencia de un personaje con un disco solar motivo que no aparece en la peña-cueva (fig. 9).

torio en el Lienzo de Guevea", Guchachi Reza, 29 (1998): 64. La arqueología confirma la mayor presencia en la zona sur del istmo de materiales de los valles centrales en el Posclásico tardío. Véase Alma Montiel Ángeles, Víctor Zapién López, Marcus C. Winter y Gonzalo Santiago Sánchez, "La arqueología del istmo oaxaqueño: patrones de asentamiento, comunidades y residencias", en Panorama arqueológico: dos Oaxacas, eds. Marcus C. Winter y Gonzalo Santiago Sánchez (Oaxaca de Juárez: Instituto Nacional de Antropología e Historia/ Consejo Nacional para la Cultura y las Artes, 20I4), 197-244. Los pocos estudios realizados afirman que la ocupación se centró en las orillas de los ríos Tehuantepec y Los Perros, en forma de sitios pequeños. Judith Francis Zeitlin, y Robert N. Zeitlin, "Arqueología y época prehispánica en el sur del Istmo de Tehuantepec", en Lecturas históricas del estado de Oaxaca. Época prehispánica, coord. Marcus C. Winter (México: Instituto Nacional de Antropología e Historia/Gobierno del Estado de Oaxaca, 1990), 448. Sin embargo, también señalan la existencia de un sitio monumental, llamado Guiengola. Su arquitectura de piedra es característica de la cultura zapoteca del Clásico y Posclásico. David A. Peterson, "Guiengola: Fortaleza zapoteca en el Istmo de Tehuantepec", en Lecturas históricas del estado de Oaxaca, 484.

En el proyecto que se desarrolla bajo mi dirección hemos descubierto en el arco montañoso otro gran sitio, El Cerro Negro, de monumentalidad similar a Guiengola, como también otros sitios pequeños de diferentes funciones. 

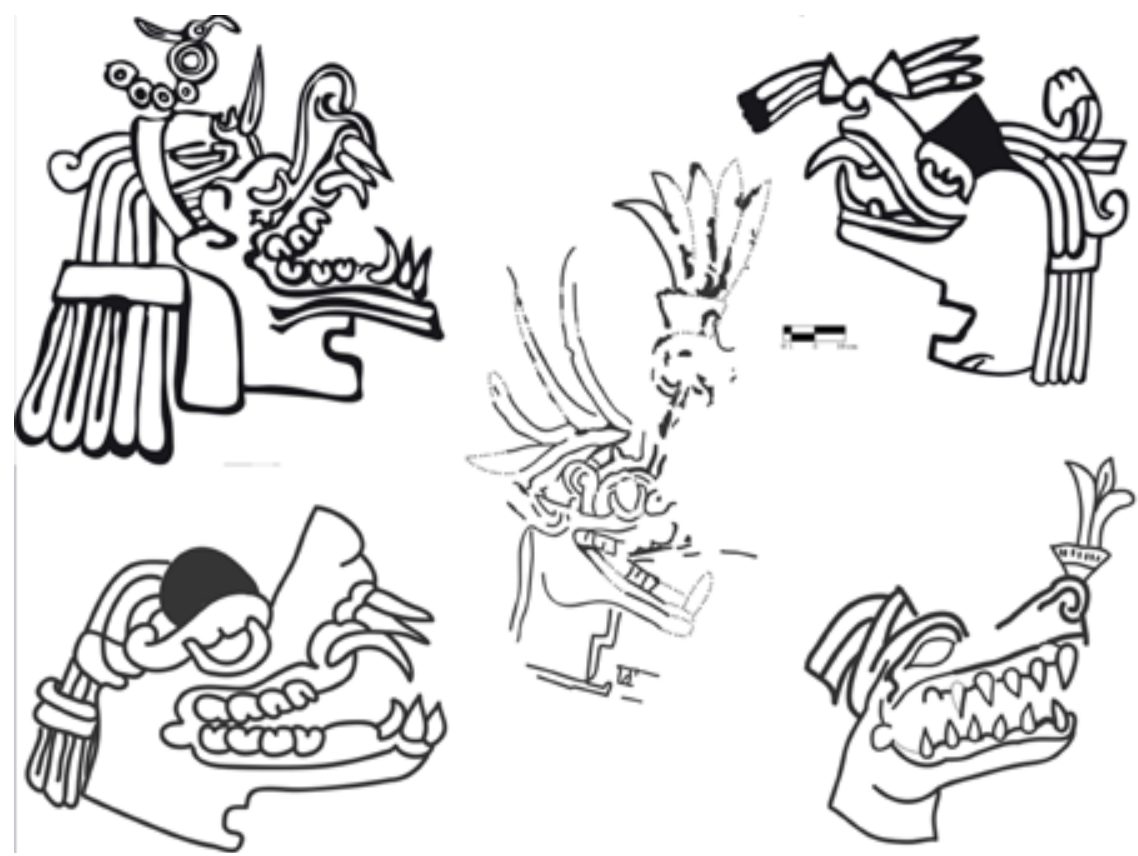

8. Dibujos de un tipo de motivo recurrente en las pinturas de Ba'cuana: cabezas de un ser extraordinario, una gran serpiente guardiana a la que se le hacían peticiones en el sitio.

\section{Las imágenes coloniales}

En este trabajo trato de aproximarme a la historia de este lugar sagrado desde que llegaron los españoles hasta el siglo XIX, centrándome, con base en el estudio de las realización de imágenes, en cómo se desarrolló el culto en el mismo y cómo evolucionó la percepción de este lugar sagrado en la región.

Como se pueden apreciar diferencias notables en la manera en que fue intervenida cada roca, primero nos acercaremos a la peña-parada con sus imágenes bien dispuestas a la vista de todos, y luego a las pinturas escondidas en la penumbra de la peña-cueva. Voy a ir argumentando las razones de mi atribución de las imágenes a diferentes fases, las posibles interpretaciones, y la relación con las imágenes anteriores, tanto prehispánicas como coloniales, es decir, con el estado de la obra rupestre cuando se pintaron esos motivos. 


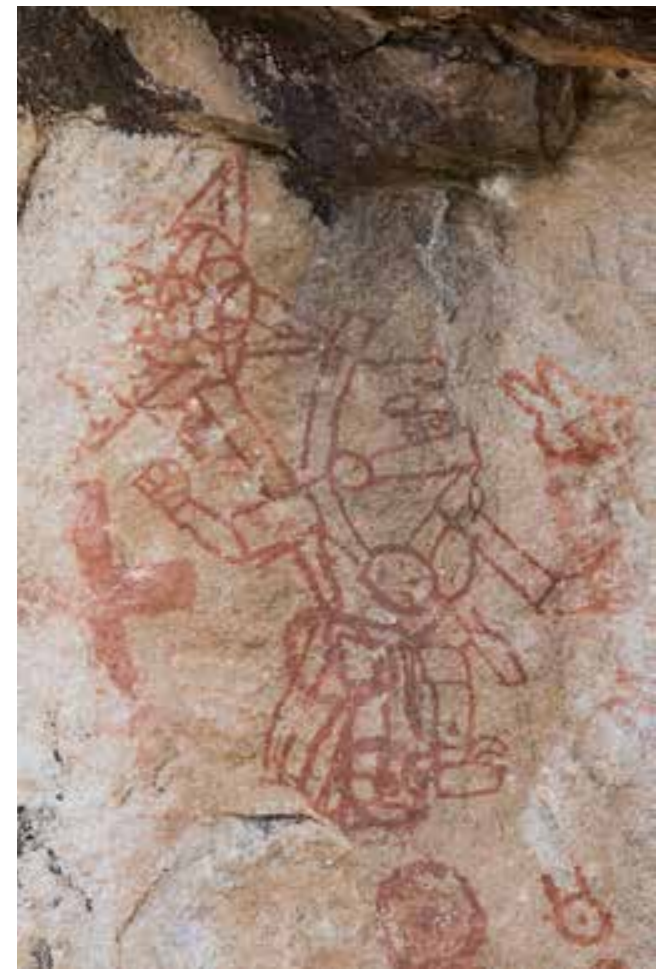

9. Motivo de personaje relacionado con un disco solar en la parte superior izquierda. Roca 2, panel I. Foto: Fernando Berrojalbiz.

Con el fin de diferenciar los motivos de época prehispánica de los coloniales, e incluso, dentro de estos últimos, para establecer las diferentes etapas de ejecución a lo largo de los tres siglos de este periodo se combinaron estudios de estilo, iconográficos y los análisis de pigmentos, ya que en muchos casos cada uno de estos estudios por separado ha demostrado no ser suficiente. ${ }^{6}$ Cruzando informaciones de estos tres tipos de acercamiento aporto argumentaciones sólidas para la diferenciación de etapas de ejecución de las pinturas.

6. En este trabajo se explicarán a detalle los resultados de los análisis de los motivos que se analizan en el texto con detenimiento, el análisis de pigmentos se realizó a una gran cantidad de motivos que recogen la diversidad de imágenes del sitio, por lo que los resultados corresponden y están respaldados por una gran cantidad de mediciones y no sólo de los motivos que se comentan con minuciosidad. 
Io. Panel I de la roca 2. Foto: Fernando Berrojalbiz.

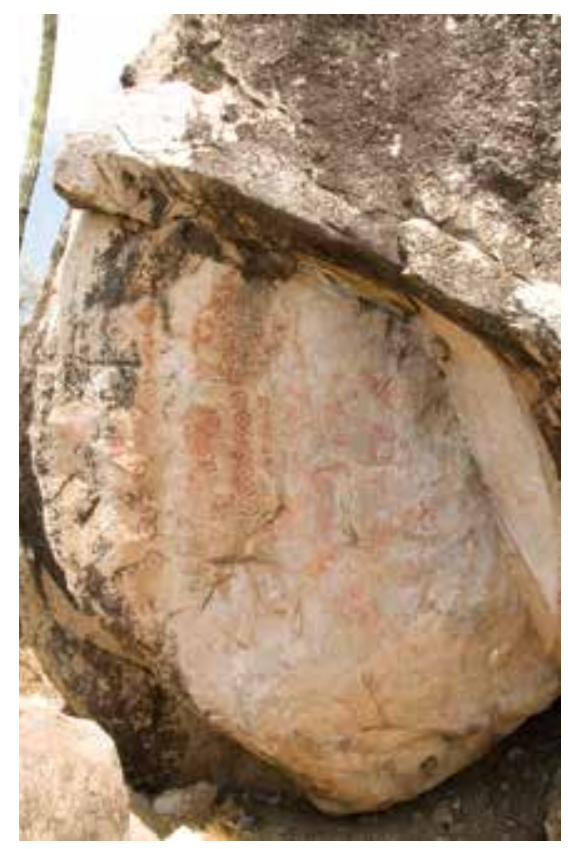

\section{La peña parada en el siglo XVI}

Al comparar las intervenciones efectuadas a lo largo del periodo colonial sobre los dos paneles con pinturas en esta gran roca, es evidente el paulatino alejamiento de la antigua tradición en todos los niveles, en los pigmentos utilizados, en el estilo y en el repertorio.

La primera intervención parece haberse realizado en el panel I en el que se encuentra la mayoría de los motivos prehispánicos (fig. Io). En un principio creí que todos habían sido pintados en esa época. Sin embargo, existe un motivo que ya había observado que se diferenciaba de los demás por su estilo. Está ubicado en el borde derecho de este panel, junto al límite del panel 2, y en la parte inferior. Se trata de un antropomorfo, posiblemente un guerrero por las flechas que porta en la única mano que se ha conservado (fig. II). Está representado de perfil, y con las piernas abiertas en actitud de caminar. Porta sandalias. ${ }^{7}$

7. Las dimensiones de los motivos descritos se pueden apreciar en cada uno de los dibujos ya que todos incluyen una escala. 


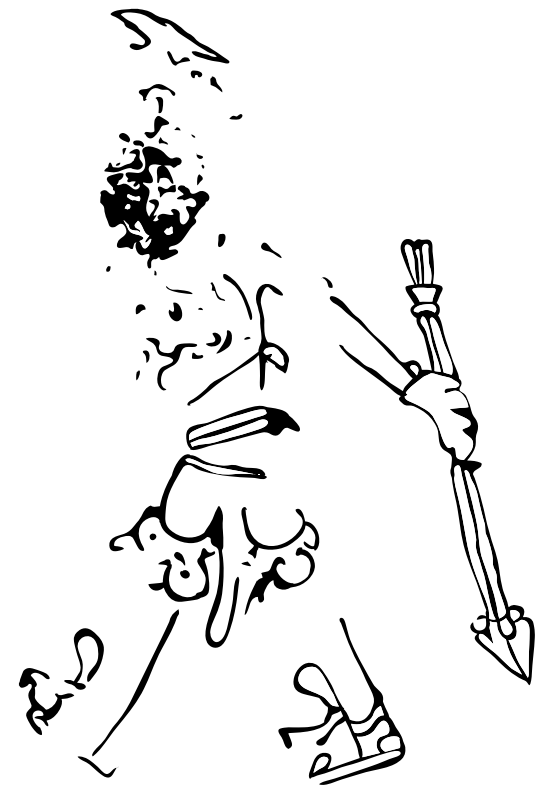

II. Motivo de personaje del panel I de la peńa-parada, con aspectos de estilo europeo. Dibujo: José Moisés Cerero Arellano.

Varios aspectos indican un estilo diferente del resto de motivos del panel, de factura prehispánica, como del estilo Mixteca-Puebla en general. En primer lugar la figura está plasmada con una línea más fina que la de los motivos prehispánicos, y la calidad del dibujo es bastante buena. La tonalidad del color rojo es algo diferente, un poco más clara. Las proporciones de la figura humana son mayores y más alargadas que las típicas del estilo Mixteca-Puebla, siendo muy parecidas al canon europeo. También las flechas siguen esas proporciones.

El paño de cadera o braguero tiene una forma diferente de las representaciones prehispánicas y porta una especie de chalchihuites pegados al borde inferior. El pedazo de tela que cae por delante es estrecho y más corto.

El análisis de pigmentos indica que esta pintura tiene una menor cantidad de hierro que las prehispánicas, y además presenta un incremento en el contenido de manganeso, no presente en aquéllas. ${ }^{8}$ Esto, junto con las diferencias de estilo que acaban de mencionarse sustenta la idea de que este motivo se hizo en

8. Desafortunadamente no existen estudios sobre pigmentos de arte rupestre de los zapotecos en los valles centrales ni en el istmo, ni para la época prehispánica ni para el periodo colonial, por lo que no tenemos otras evidencias con las cuales comparar nuestros estudios. 


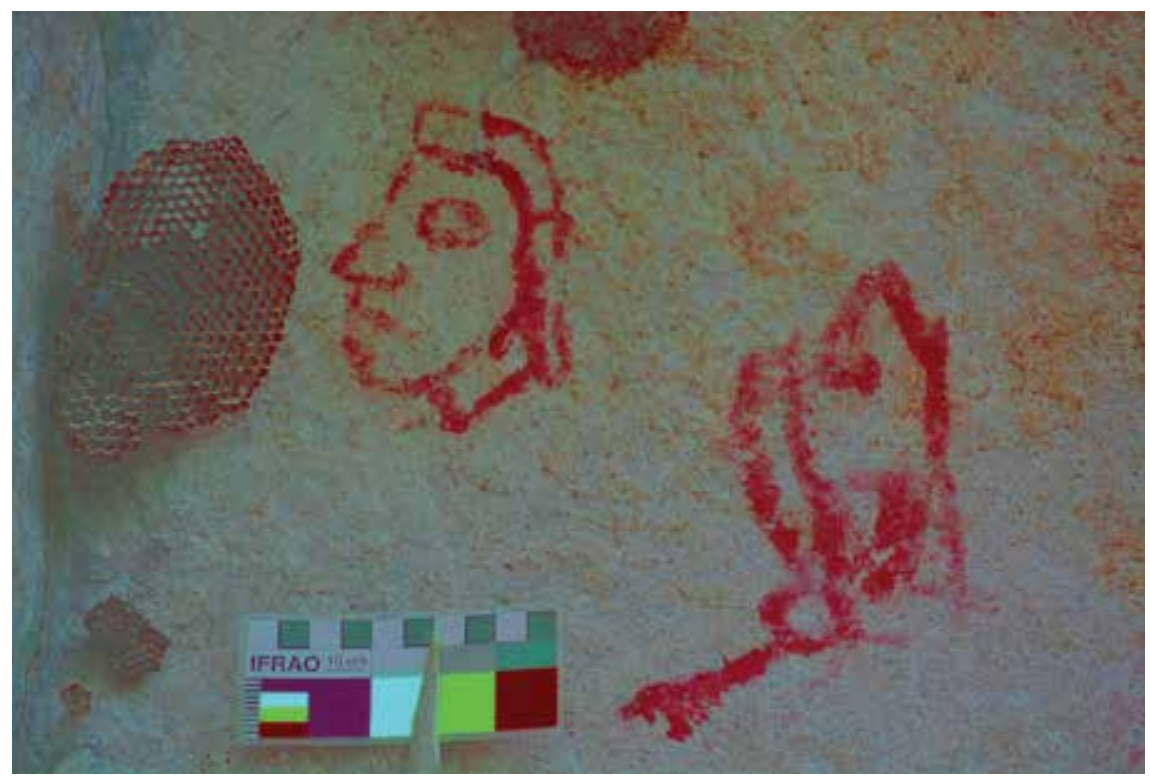

I2. Una cabeza antropomorfa y un motivo en el estilo de Arma Christi, del siglo Xvi. Sitio Ba'cuana, peña-parada, panel 2. Foto: Pedro Ángeles. Tratamiento con el programa Image J y el plug in Dstretch de Fernando Berrojalbiz.

época colonial, no mucho tiempo después de la Conquista. Aparentemente, a pesar de los cambios aportados por la Conquista, se mantuvo el interés por el mensaje plasmado en las imágenes antiguas y quizá también se conservaba en gran medida su plena comprensión.

Los otros motivos coloniales en esta roca se concentran en el panel 2 y parecen haber sido pintados a lo largo de un extenso periodo. La etapa más antigua se sitúa en la posición más alta y corresponde a dos motivos: una cabeza antropomorfa y la posible representación de dos manos juntas.

La cabeza está representada de perfil, viendo hacia la izquierda del espectador (fig. 12). La tonalidad del color es roja, un poco más clara que los motivos del panel I. El trazo es bastante firme, de calidad media ${ }^{9}$ y de un grosor parecido a los motivos prehispánicos del panel I, o incluso menor.

9. Incluyo los tres niveles de calidad del trazo y del dibujo que he considerado para las imágenes del sitio Ba'cuana. Alta: línea regular, de trazo firme, dibujo bien logrado y se aprecia un cuidado en las proporciones de las partes, su propio equilibrio. Imágenes de gran expresividad. 
Destacan dos elementos de esta cabeza que me llevan a pensar que se realizó después de la Conquista: la presencia del cuello, pintado como un bloque rectangular que sigue la inclinación de la mandíbula, y un trazo horizontal encima del ojo, por debajo de la línea del pelo, casi pegado a esta última, pero claramente separado. En mi opinió, éste representa la ceja. En los principales medios en los que se usó el estilo Mixteca-Puebla antes de la Conquista, como los códices o la cerámica polícroma, estos dos elementos no aparecen en las representaciones humanas (salvo raras excepciones). En cambio, en los códices coloniales son frecuentes. ${ }^{\text {IO }}$

Existe otro motivo que está junto al que acabo de analizar, a su derecha y un poco más abajo (fig. I2). Tiene la misma tonalidad de rojo, el mismo tipo de trazo y dimensiones similares, por lo que parecen estar relacionados.

No es fácil identificar qué representa este motivo. Una primera hipótesis es que se trata de dos manos unidas por las palmas, con los pulgares hacia el lado izquierdo, en actitud de orar. En la iconografía cristiana es muy frecuente este gesto para mostrar que el personaje, representado de cuerpo entero, está rezando. Sin embargo, la aparición de dos manos juntas aisladas, sin el cuerpo, en el gesto de orar es muy raro; de hecho no he encontrado esta representación en imágenes cristianas de la época.

Además, en la parte inferior izquierda, en su base, existe un círculo del cual sale una línea en ángulo de 45 grados aproximadamente hacia el cuadrante inferior izquierdo. Por la muesca que se encuentra en el engrosamiento del extremo, una interpretación podría ser una especie de llave.

La iconografía cristiana más cercana que he notado respecto de estos dos motivos es la llamada Arma Christi, o los instrumentos de la Pasión de Cristo, ${ }^{\text {II }}$ estrechamente relacionada con el tema de la misa de San Gregorio, temas y motivos populares en los últimos tiempos de la época medieval y al comienzo del Renacimiento, y que pasaron a la Nueva España en diferentes soportes,

Media: línea regular, trazo firme, aunque se aprecian algunas dudas o irregularidades. El dibujo es correcto, pero no tan bien logrado como en el de calidad alta, ni tampoco logra la misma expresividad. Tosca: línea irregular, trazo a veces con incorrecciones. Dibujo no bien logrado, las proporciones no están cuidadas. La expresividad es escasa.

IO. Telleriano Remensis, 4Ir; Códice Florentino, lib. I, f. 22v; Los señores de Texcuco, lib. 8, fol. $7 \mathrm{v}$.

II. Linda Báez Rubí, "Ecce homo: el cuerpo, los sentidos y la imaginación en los ejercicios de meditación mística”, en Los itinerarios de las imágenes, prácticas, usos y funciones, eds. Linda Báez, Emilie Carreón y Deborah Dorotinsky (México: Universidad Nacional Autónoma de MéxicoInstituto de Investigaciones Estéticas, 20IO), II3. 
I3. Misa de San Gregorio: Arte plumario. Misa de San Gregorio, México, I539. Esta obra fue realizada durante el gobierno de

Diego de Alvarado Huanitzin. Mosaico de plumas sobre algodón, amate y madera.

Museo de los Jacobinos, Auch, Francia.

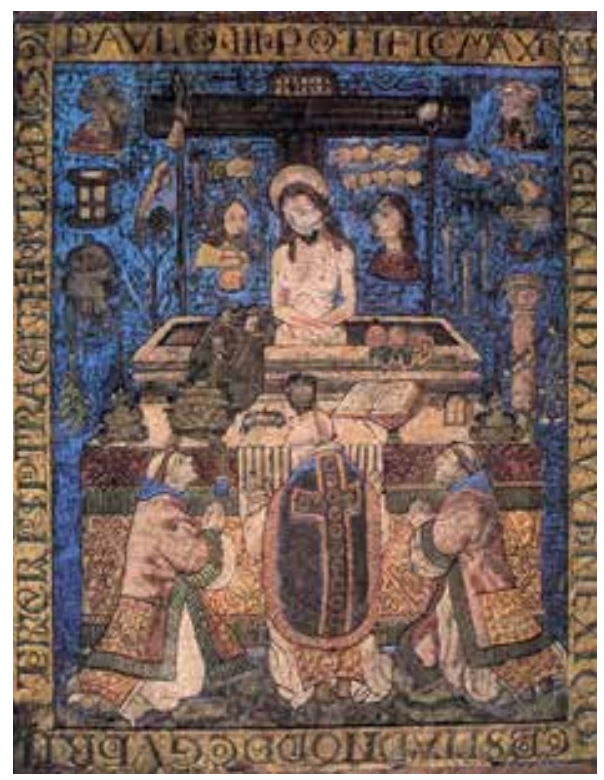

como la magnífica misa de San Gregorio en arte plumario de 1539 (fig. 13). ${ }^{12}$ Las armas de Cristo, además de representar objetos, en la forma de armas heráldicas conquistadas por Cristo en la Pasión, incluyen otros elementos como rostros y manos en diferentes actitudes. Las caras pueden corresponder a detractores de Cristo, o por el contrario, personas que sufrieron con su Pasión, como Juan. Las manos pueden corresponder a la mano de Caifás, o a la de san Pedro con una llave entre los dedos. Pero no he encontrado la representación de dos manos en el gesto de orar, como parte de las armas de Cristo.

Como otra opción de interpretación he encontrado que en varias pinturas con el tema de Arma Christi del siglo xv procedentes del centro de Europa se representa una mitra de obispo, dibujada con dos líneas paralelas de un lado, queriendo utilizar algo de perspectiva para representar los dos elementos triangulares de la mitra, uno detrás de otro. ${ }^{13} \mathrm{La}$ forma de la mitra y el tipo de

I2. Elena Isabel Estrada Cuesta de Gerlero, Muros, sargas y papeles, imagen de lo sagrado y lo profano en el arte novohispano del siglo XVI (México: Universidad Nacional Autónoma de MéxicoInstituto de Investigaciones Estéticas, 20II), 192.

I3. Altar of the Holy Kinship (closed). wikimediacommons. File: Altar of the Holy Kinship 
DOI: https://doi.org/10.22201/iie.18703062e.2020.116.2718

I88

FERNANDO BERROJALBIZ

representación se parecen al motivo de este panel de Bảcuana. En este caso, la línea en dirección al cuadrante inferior izquierdo podría ser una de las ínfulas de la mitra, con una borla o flecos en su extremo.

En cualquiera de las dos interpretaciones, estoy considerando que se trata de motivos pintados por los zapotecos del siglo XVI, en un lugar sagrado de su tradición y fuera del control o supervisión de autoridades o religiosos, por lo que es muy posible que estuvieran reinterpretando y recomponiendo imágenes de diversas fuentes, pinturas, libros o grabados, que hubieran conocido. Por tanto, no sería tan descabellado que plasmaran las Arma Christi como ellos las visualizaban, mezclando ideas, detalles e imágenes de diferente origen, o incluso pintando los elementos originales desde perspectivas distintas y con formas de representación que corresponden a otros simbolismos dentro de la religión católica, como las manos en actitud de orar.

Otro de los argumentos a favor de que estos dos motivos estarían relacionados con las Arma Christi es que estas últimas se podrían considerar como pictogramas o ideogramas medievales, y el sistema de escritura o de registro del Posclásico, usado en las expresiones prehispánicas en Ba'cuana, se compone principalmente de ideogramas y pictogramas, por lo que ambos sistemas plásticos de comunicación tendrían muchos aspectos en común, ${ }^{\mathrm{I}} \mathrm{y}$ los signos de las Arma Christi serían fáciles de asimilar por los zapotecos. Sin embargo, en el caso del segundo motivo, los zapotecos reinterpretaron e introdujeron cambios en la iconografía, por lo que es difícil de interpretar ahora.

Los mensajes asociados a estos dos motivos, al parecer, se refieren a iconografía cristiana, en concreto a las Arma Christi, por lo que se podría pensar que eran los primeros temas de un programa más amplio consistente en pintar en este panel el conjunto de las armas de Cristo, pero que quedó interrumpido.

El análisis que está realizando un equipo de físicos de la UnAM sobre los pigmentos indica, acerca de estos dos elementos, que el pigmento tiene una composición diferente de la de los prehispánicos ya que contiene menos hierro, por lo que se parecen al motivo colonial del panel I arriba descrito y, en cambio, tienen más contenido de calcio. También se diferencian de otros motivos coloniales presentes en este panel 2, a los que me referiré en el siguiente apar-

(closed). https://commons.wikimedia.org/wiki/File:Altar_of_the_Holy_Kinship_(closed).jpg, consultado el is de marzo de 2018.

I4. Serge Gruzinski, La guerra de las imágenes: de Cristóbal Colón a Blade Runner (I492-2019) (México: Fondo de Cultura Económica, 2012), 89. 
tado, que se caracterizan por un muy bajo contenido en hierro o en algunos casos inexistente. ${ }^{15}$

Por el uso de un sistema de pictogramas al modo antiguo, pero con modificaciones en los motivos o la introducción de repertorio cristiano, por el uso de un canon diferente al del estilo Mixteca-Puebla en la representación del cuerpo humano, y por el pigmento utilizado, que ya no permite obtener fuertes tonalidades rojas, considero que estos motivos del posible guerrero e imágenes similares a las Arma Christi constituyen una primera etapa en la reutilización de la peńa, apegada todavía a la usanza artística antigua pero correspondiente a una influencia europea y a una cristianización incipiente.

\section{Peña parada: imágenes de los siglos XVII y XVIII}

Después de esas primeras reutilizaciones de la peña, ésta siguió atrayendo a los habitantes de la región para plasmar imágenes sagradas en el siglo XVII o XVIII. Aunque tengo argumentos para decir que no se realizaron en el siglo XVI, resulta difícil establecer con certeza si se produjeron en el XVII o en el XVIII. Uno de los aspectos que comparten todas estas imágenes, incluidas las que analizaré más tarde de la peña-cueva, es que están hechas con un pigmento diferente de los motivos prehispánicos y de los motivos del siglo XVI, especialmente por la menor cantidad de hierro o su inexistencia, por lo que su color es entre naranja y amarillo.

I5. El equipo del Instituto de Física llevó a cabo un análisis de la composición elemental de los pigmentos en este sitio. Dicho análisis demuestra, junto con informaciones de estilo e iconografía, que de manera repetida y consistente se observa una diferencia entre la composición de los pigmentos prehispánicos y los coloniales. Este tipo de análisis para arte rupestre apenas está comenzando en México. En otros países ha permitido abundar sobre los cambios de las pinturas en el tiempo: "los resultados obtenidos pueden contribuir a reflexionar sobre las diferentes facetas de las dinámicas sociales de los pueblos en el pasado, en el sentido de evaluar su movilidad o sus posibles interacciones. Es posible también identificar la presencia de innovaciones tecnológicas, como también los cambios que ocurren en el tiempo. En otras palabras, nosotros podemos preguntarnos sobre el conocimiento necesario para que ocurran estos cambios. ¿En qué contextos sociohistóricos sucedieron? ¿Qué factores desencadenaron o empujaron estas transformaciones?". Véase Marcela Sepúlveda, "Methodological Approach to the Materiality of Rock Paintings Based on Their Physicochemical Characterisation. Proposal and Reflections from Their Study in Chile", en Paleoart and Materiality. The Scientific Study of Rock Art, eds. Robert G. Bednarik, Danae Fiore, Mara Basile, Giriraj Kumar y Tang Huisheng (Oxford: Archeopress, 2016), 66. 
DOI: https://doi.org/10.22201/iie.18703062e.2020.116.2718

190

FERNANDO BERROJALBIZ

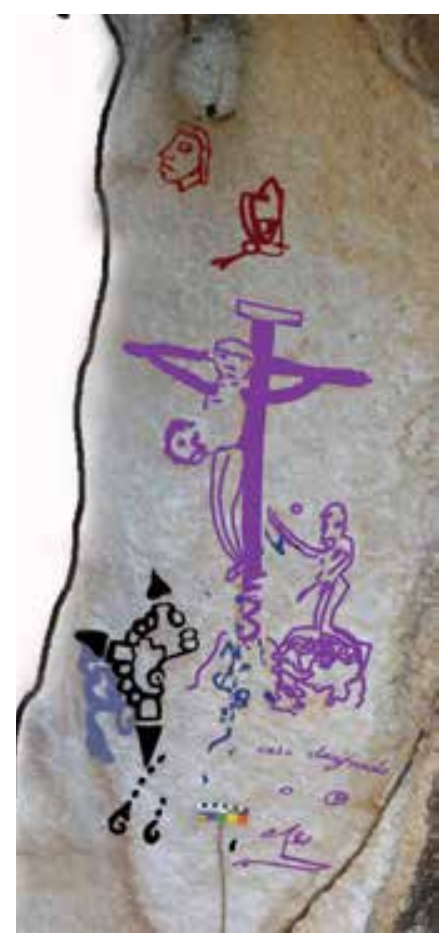

I4. Dibujos sobre foto de los motivos del panel 2 de la peña-parada del sitio Ba’cuana. Foto: Fernando Berrojalbiz. Dibujos: José Moisés Cerero Arellano.

En el centro del panel 2, destaca una escena que muestra a Cristo crucificado en una cruz que se erige sobre una roca a la manera de una vera effigie (retrato pictórico de esculturas devocionales cristianas) (figs. I4 y I5); en la base de la cruz, hacia el lado derecho según el punto de vista del espectador, una persona está arrodillada sobre otra roca en actitud de adoración hacia el Cristo. El color es entre café claro, anaranjado y amarillo. Analicé este grupo de figuras en un trabajo anterior, ${ }^{16}$ por lo que resumiré las características y las conclusiones a las que llegué, además de añadir algún dato nuevo y comentar los resultados de los análisis de pigmentos recientemente realizados.

En los diferentes elementos que componen la escena se alternan la plasmación de la imagen mediante el contorno y mediante partes rellenas en tinta plana del mismo color, por lo que hay un juego de dos colores, el de la pintura

I6. Berrojalbiz, "La Ba'cuana, Istmo de Tehuantepec: el encuentro de dos tradiciones en un lugar sagrado", 358-362. 
DOI: https://doi.org/10.22201/iie.18703062e.2020.116.2718

UN LUGAR SAGRADO EN EL ISTMO DE TEHUANTEPEC

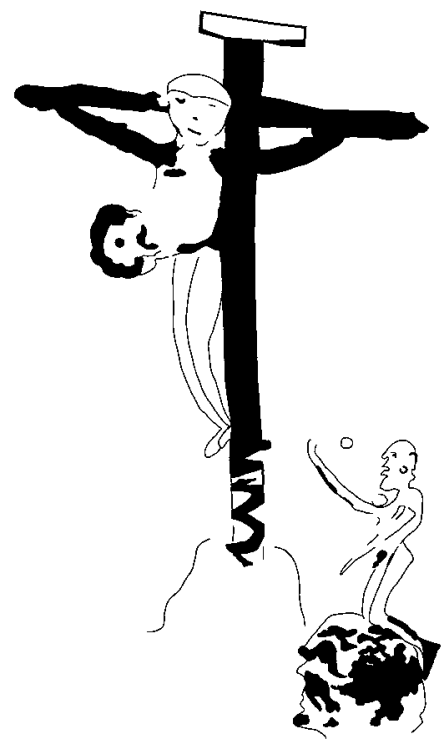

I5. Dibujo del Cristo crucificado y el personaje arrodillado del panel 2 de la peña-parada del sitio Ba'cuana. Dibujo: Fernando Berrojalbiz con la colaboración de Citlali Coronel.

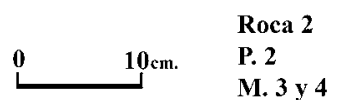

y el de la roca que se deja ver en las partes sólo en la silueta. En las partes en que se plasma sólo el contorno la línea es más fina que la de los motivos prehispánicos, incluso más que los dos ideogramas coloniales en la parte superior. El trazo es firme, de calidad media.

En cuanto a su formato, iconografía y composición pertenece a la tradición iconográfica religiosa occidental. Sin embargo, se notan algunos elementos de tradición indígena, mismos que se pueden apreciar en los recursos plásticos, la importancia del contorno en el dibujo, pero también en la iconografía, los motivos prehispánicos en el personaje arrodillado, y en los simbolismos y mensajes encerrados en los mismos, como en la flor junto a la cadera de Cristo.

Para el personaje arrodillado la hipótesis que considero más aceptable es que se trata de san Jerónimo, ya que es el santo patrono de Ixtepec, a cuyos límites se sitúa Ba'cuana. Sin embargo, se encuentra representado totalmente desnudo, más propio de la tradición pictórica prehispánica, con el mentón pronunciado, como se representaba la vejez en dicha tradición, y con una posible orejera, elemento suntuario típico mesoamericano. 
DOI: https://doi.org/10.22201/iie.18703062e.2020.116.2718

I92

FERNANDO BERROJALBIZ

La flor en la cadera, como desarrollo elaborado del cendal, comenzó a aparecer en diversas imágenes escultóricas de bulto redondo de Cristo, hacia finales del siglo Xviı en la Nueva España. ${ }^{17}$ Estas imágenes escultóricas que producían una devoción ferviente profesada por una gran cantidad de fieles se plasmaron mediante la pintura (verae effigies), y a partir de ese periodo se incluyeron también estos elementos del cendal tan elaborados. ${ }^{18}$ Posteriormente circularon estas imágenes en grabados y estampas. La hipótesis que establecí en un trabajo anterior, a falta de una explicación dentro de la historia del arte religioso novohispano (ya que no se observa ni en España ni en otros virreinatos) de la aparición de este elemento, es que proviene de la tradición mesoamericana.

Diversos autores han señalado que el líquido precioso, la sangre, que se ofrendaba a los dioses en época prehispánica se identificaba en la colonia con la sangre de Cristo durante la pasión y su muerte en la cruz. ${ }^{19}$ Entre los recursos utilizados en esta analogía se encuentra el motivo de una flor que en la tradición posclásica mesoamericana es una metáfora de la herida sacrificial. Esta metáfora se puede encontrar tanto en la poética de la tradición nahua ${ }^{20}$ como en la iconografía de los códices de tradición Mixteca-Puebla del Posclásico. ${ }^{21}$ En el siglo Xvi, en diversas obras se puede observar la confluencia de la imagen de una flor y la sangre relacionada con la cruz. ${ }^{22} \mathrm{Al}$ seguir esta línea de interpretación el motivo que aparece en el costado de Cristo, como desarrollo del cendal, podría ser una flor como metáfora de la sangre sacrificial dentro del lenguaje simbólico de la tradición mesoamericana. Los zapotecos durante la colonia al observar dicho motivo en imágenes que pudieron llegar al ist-

17. Comunicación personal con Pablo Amador y Alena Robin.

I8. Roberto Alarcón Cedillo y María del Rosario García de Toxqui, Pintura novohispana. Museo Nacional del Virreinato, Tepotzotlán (México: Asociación de Amigos del Museo Nacional del Virreinato, 1994), 58 y 75.

I9. Pablo Escalante, "Cristo, su sangre y los indios. Exploraciones iconográficas sobre el arte del siglo XVI", en Herencias indígenas, tradiciones europeas y la mirada europea, ed. Helga von Kügelgen (Madrid: Vervuert-Iberoamericana, 2002), 7I-79; Ana G. Díaz, Rocío Gress, Marie-Areti Hers y Francisco Luna Tavera, "El Cristo otomí: arte rupestre, fiesta y sacrificio en el Mezquital", en La vitalidad de las voces indigenas: arte rupestre del contacto y en sociedades coloniales, ed. Fernando Berrojalbiz (México: Universidad Nacional Autónoma de México-Instituto de Investigaciones Estéticas, 2015), 384-385.

20. Escalante, "Cristo, su sangre y los indios", 77.

2I. Códice Borgia, lám. 42.

22. Escalante, "Cristo, su sangre y los indios", 77. 
mo, como pinturas, grabados o estampas, lo reconocieron y lo reactivaron en sus propias expresiones.

Varios aspectos analizados señalan la factura de esta imagen hacia finales del siglo XVII y principios del siglo XVIII. ${ }^{23}$ Sobre la interpretación de las imágenes, siguiendo la simbología cristiana, esta escena muestra la redención de la humanidad por medio del sacrificio de Cristo, el perdón del pecado original, y por tanto un renacimiento. La cruz se convierte en árbol de vida, en el símbolo de la salvación, pero también de fertilidad. Una de las conclusiones del análisis que realicé es que existía una concordancia de simbolismos, de mensajes, entre los prehispánicos —explicados más arriba cuando se trató de los mensajes de las pinturas, que exaltan la fertilidad del mundo, el milagro de la vida - y los cristianos, con relación a la fertilidad y a la renovación de la vida. ${ }^{24}$ Esto queda acentuado además por el hecho de pintar el conjunto colonial junto al prehispánico, pero sin taparlo o negarlo, al contrario, poniendo en diálogo ambas mentalidades, ambos mensajes, como ha sido señalado para otros conjuntos rupestres coloniales en México. ${ }^{25}$

Existen unas palabras escritas debajo de la escena del Cristo crucificado (fig. I6). Se trata de unos pocos vocablos, y dos especies de rúbricas que se distribuyen en tres líneas debajo del personaje arrodillado, hacia el lado derecho, casi en el borde inferior del panel. Se encuentran bastante borradas por lo que es difícil su identificación. En un trabajo anterior, señalaba que la transcripción de la primera línea podría ser cosa testificadola. Ahora incluyo la posibilidad de que la primera palabra sea causa y la segunda desifradola [sic]. Ambas palabras, testificar como descifrar se usaban a finales del siglo XVII y principios del XVIII. ${ }^{26}$ En la segunda línea, otra lectura a la rúbrica, sería que los dos signos son letras muy borradas como la $\mathrm{A}$ y la $\mathrm{O}$, imitando a las letras griegas alfa y omega como principio y fin, otra manera de referirse a Dios. La última línea sí parece una firma y rúbrica que no he podido identificar.

23. Berrojalbiz, "La Ba'cuana, Istmo de Tehuantepec", 349.

24. Berrojalbiz, "La Ba'cuana, Istmo de Tehuantepec", 350.

25. Marie-Areti Hers, Alfonso Vite y Vanya Valdovinos, "Arte rupestre: identidad y dominio territorial en tiempos coloniales", en La vitalidad de las voces indígenas: arte rupestre del contacto y en sociedades coloniales, ed. Fernando Berrojalbiz (México: Universidad Nacional Autónoma de México-Instituto de Investigaciones Estéticas, 2015), 53.

26. Diccionario de autoridades. Real Academia Española [1732], http://www.rae.es/recursos/ diccionarios/diccionarios-anteriores-1726-1996/diccionario-de-autoridadeshttp://web.frl.es/ DA.html, consultado en marzo de 2018. 


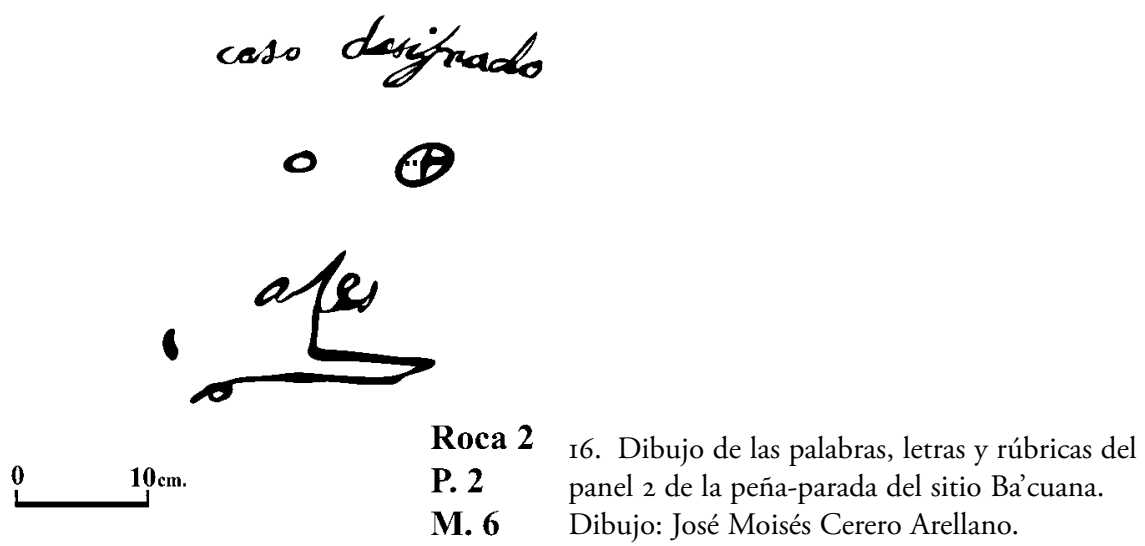

Respecto al análisis de pigmentos, en el Cristo crucificado y en el personaje arrodillado se observó una cantidad muy baja de hierro, mucho menor que en los motivos prehispánicos, y también menor que en los dos elementos superiores de la cabeza y las manos orando. En las letras se observó que no había hierro en el pigmento. Esto indica que existe una diferencia marcada entre estos motivos de los siglos XVII o XVIII, los dos superiores y los prehispánicos. En cuanto a los coloniales, estos análisis podrían mostrar dos etapas diferentes de ejecución, pero esperaré a comentar primero qué ocurre con los pigmentos de los motivos coloniales de la peńa-cueva para poder establecer una opinión más fundamentada.

En esta roca - la peña-parada, la que recibe el sol casi todo el día, desde la Conquista y a lo largo del periodo colonial-, los zapotecos de la zona trataron de apropiarse y plasmar su versión de los nuevos dioses y de las nuevas ideas y simbolismos, concretamente alrededor de la figura de Cristo (¿el nuevo sol?) y su Pasión. El panel 2 no se había utilizado en época prehispánica, salvo por un motivo. Con la intención bastante evidente de no perjudicar a la obra prehispánica, en el siglo XvI parece que se propusieron pintar las Arma Christi, para representar a ese nuevo dios mediante un sistema pictográfico similar al suyo, aunque pareciera un proyecto inconcluso. Siglo y medio más tarde, pintaron a ese nuevo dios, el Cristo en la cruz, con un personaje arrodillado a sus pies venerándolo, esta vez empleando los recursos plásticos e iconográficos europeos, pero incluyendo aspectos estilísticos y simbólicos de raigambre prehispánica. Otra vez se aprecia esa voluntad de diálogo entre los antiguos 
simbolismos y maneras de entender el mundo y los nuevos dioses y las nuevas explicaciones de dicho mundo. Aunque se observa que las antiguas tradiciones tienen menos presencia, hay un intento de aferrarse a ellas, transformándolas y adaptándolas en la medida de lo posible.

\section{La peña-cueva: el Cristo ofrendado}

En diversas ocasiones, desde los primeros tiempos coloniales y a lo largo de todo el virreinato, el oscuro abrigo formado por la roca fue visitado para dejar nuevas improntas. Lo singular de esas acciones es que en la mayoría de los casos los motivos antiguos se intervinieron directamente, transformando su sentido original.

Como en el caso de los motivos pintados en la peña-parada en el siglo xvı, la intervención colonial más antigua sobre el techo de la peña-cueva utilizó, para su plasmación, el sistema pictográfico o sistema de registro del Posclásico y la tradición Mixteca-Puebla, a pesar de haberse introducido modificaciones en la técnica, el estilo y la iconografía.

En el techo, cerca de la entrada noroeste, existe una franja blanquecina, consistente probablemente en una capa de minerales causada por escurrimientos continuos de agua, los cuales ocultaron algunas imágenes. Sin embargo, al hacer uso de ciertos programas de computación ${ }^{27}$ se pudieron ver las imágenes tapadas, de factura antigua, pero con una intervención posterior que unió dos motivos y transformó su sentido (fig. 17).

En la parte inferior de la imagen (fig. I8), se aprecia una banda horizontal con tres puntos en su interior que descansa sobre dos cuadritos. Esta parte consiste en la representación de una vasija cerámica vista de perfil. Durante el Posclásico, en la cultura zapoteca una de las formas cerámicas más recurrentes era el cuenco, de paredes de diversas formas, pero con tres soportes o patas. ${ }^{28}$ Tanto en los códices prehispánicos como en la pintura rupestre al representarse de perfil, sólo se pintaban dos soportes, y un cuerpo rectangular o en forma troncocónica. En Ba’cuana abundan las representaciones de estas vasijas, enci-

27. Con el programa Image J y el plug-in Dstrecht, desarrollado por John Harman.

28. Alfonso Caso, Ignacio Bernal y Jorge Acosta, La cerámica de Monte Albán (México: Instituto Nacional de Antropología e Historia, 1967), 447-470; Montiel Ángeles, Zapien López y Winter, "La arqueología del istmo oaxaqueño", 229-240. 


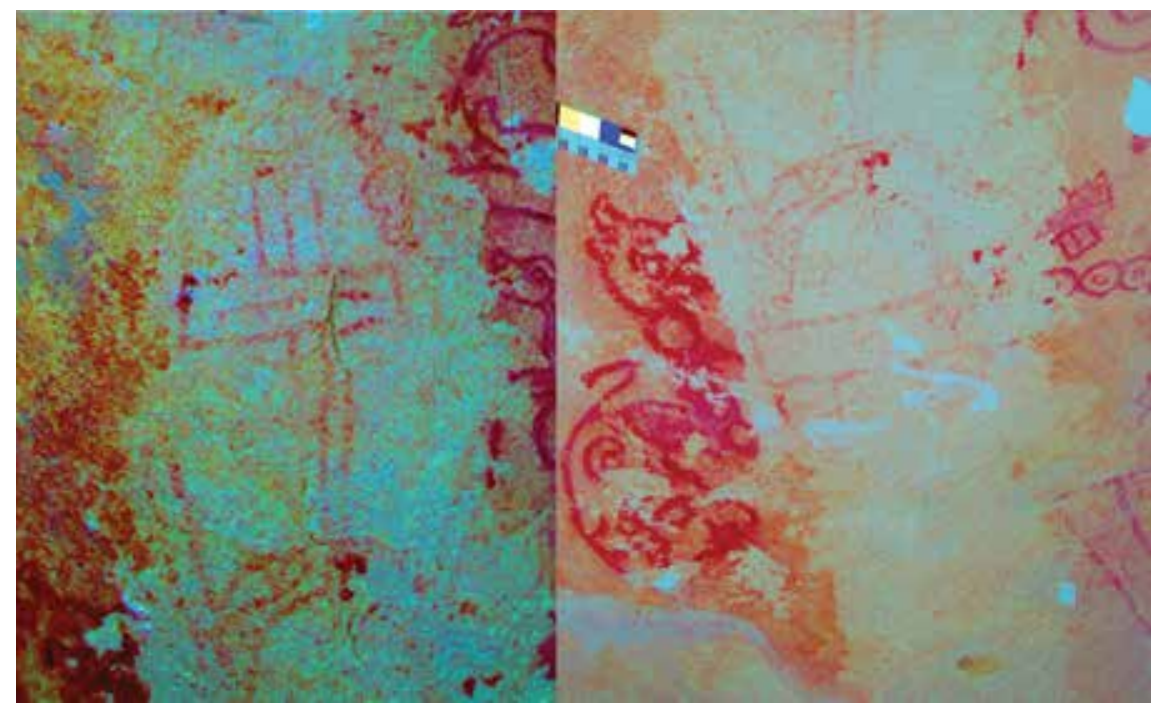

17. Parte inferior y superior del motivo de la cruz sobre un cuenco con asa canasta de la peña-cueva. Foto tratada con el programa Image J y el plug in Dstretch. Foto y tratamiento: Fernando Berrojalbiz.

ma de las cuales hay tanto plantas como animales. Este tipo de representación es una convención en la tradición Mixteca-Puebla para señalar que se trata de una ofrenda, y lo ofrendado se coloca encima de una vasija. ${ }^{29}$

En el caso de la imagen que nos ocupa se observan algunas singularidades. En primer lugar el cuerpo de la vasija es más alargado que en el resto de los ejemplos en el sitio. Sobre el cuerpo de la vasija se ha colocado una especie de arco, en el interior del cual se observan unas líneas sinuosas a modo de decoración. En mi opinión se trata de un asa semicircular que va desde un borde del cuenco hasta el opuesto. En los estudios cerámicos se denomina asa-canasta, asa-puente. A media altura de este asa-canasta, a ambos lados, surgen dos elementos longitudinales en forma vertical.

En la cerámica zapoteca del Posclásico es rara esta asa. Existen unos pocos ejemplares procedentes de una tumba en Etla, en los valles centrales, que se ha fechado en el Posclásico temprano, pero se trata de ollas chicas con una peque-

29. Miguel León Portilla, El tonalámatl de los pochtecas (Códice Fejérváry-Mayer), Arqueología Mexicana, Edición Especial Códices, núm. I8 (2005): 90. 
DOI: https://doi.org/10.22201/iie.18703062e.2020.116.2718

UN LUGAR SAGRADO EN EL ISTMO DE TEHUANTEPEC

I8. Dibujo del motivo de la cruz cristiana sobre un cuenco con asa canasta de la peña-cueva. Dibujo: José Moisés Cerero Arellano.

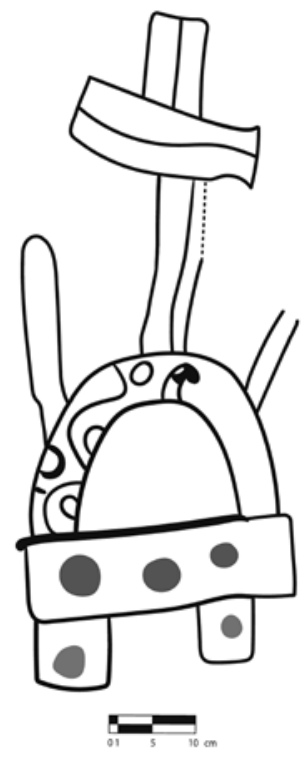

ña asa-canasta, sin decoración. ${ }^{30}$ Para el Posclásico tardío se conoce un ejemplar en los valles centrales, y en los materiales de una tumba saqueada en el istmo, en la ciudad de Tehuantepec, donde se encontraron algunos ejemplares de pequeñas jarras $\mathrm{u}$ ollas con un pequeño asa-puente en el borde, junto a otros materiales que correspondían al Posclásico tardío. ${ }^{3 \mathrm{I}}$ Pero son los únicos ejemplares hallados en el istmo y las formas son ollas o jarras.

Por otra parte, en los códices mixtecos aparecen diferentes representaciones de vasijas cerámicas, pero no he localizado ninguna que tenga este asa-canasta. No son muy abundantes los estudios sobre cerámica colonial en Oaxaca, pero entre los ejemplares encontrados en el ex convento de Santo Domingo de Oaxaca existe una jarra con dos cuellos tubulares estrechos casi verticales unidos por un corto asa-puente, sin decoración. Los autores mencionan que data de los primeros tiempos de la colonia. Ésta es, en el área de Oaxaca, la forma

30. Robert Markens, "La transición del Clásico al Posclásico en el Valle de Oaxaca: hacia las causas y consecuencias de una crisis política”, en Monte Albán en la encrucijada regional y disciplinaria. Memoria de la Quinta Mesa Redonda de Monte Albán, ed. Nelly M. Robles García y Ángel Iván Rivera Guzmán (México: Instituto Nacional de Antropología e Historia, 20II), 505.

3I. Montiel Ángeles, Zapien López y Winter, “La arqueología del istmo oaxaqueño”, 236. 
DOI: https://doi.org/10.22201/iie.18703062e.2020.116.2718

198

FERNANDO BERROJALBIZ

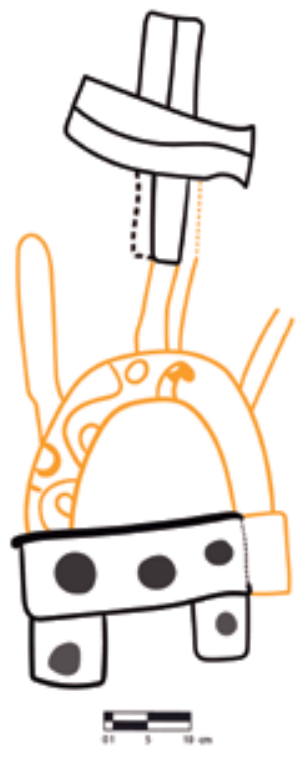

I9. Dibujo del motivo de la cruz cristiana sobre un cuenco con asa canasta de la peña-cueva. En amarillo las partes ańadidas en la colonia. Dibujo: José Moisés Cerero Arellano.

cerámica colonial más cercana al motivo analizado..$^{32}$ En cuanto a los códices coloniales he localizado en el Telleriano Remensis ${ }^{33}$ la representación de una vasija con asa-canasta, aunque la forma es de una olla. En la Ba'cuana existe un motivo prehispánico que podría representar una olla con un asa-canasta, pero es dudoso. En todo caso, la forma de olla y el asa-canasta son muy diferentes.

Sin embargo, lo que más destaca en esta imagen que estoy analizando de Ba'cuana es una cruz de brazos desiguales, similar a la cruz cristiana que se yergue en forma vertical desde la cima del asa-canasta. $\mathrm{Al}$ analizar detenidamente toda esta imagen se pudo observar que después de la conquista se aprovecharon dos motivos prehispánicos (fig. 19): un cuenco, como tantos otros representados en el sitio, y una cruz de brazos iguales, motivo común en la tradición Mixteca-Puebla y que aparece en varias ocasiones en el sitio, para componer este motivo nuevo, extendiendo el cuerpo del cuenco un poco hacia la derecha, ańadiendo el asa-puente y alargando uno de los brazos verticales de la cruz. Es difícil comentar sobre aspectos de la ejecución de este motivo ya que la capa

32. Susana Gómez y Enrique Fernández, Las cerámicas coloniales del ex convento de Santo Domingo de Oaxaca: pasado y presente de una tradición (México: Instituto Nacional de Antropología e Historia, 2007), 53.

33. Telleriano Remensis, fol. 43r. 
de minerales impide la observación directa, pero por las imágenes de computadora parece que la tonalidad de rojo y la calidad del trazo tienen similitudes con el grueso de motivos del conjunto i. Debido a que no se puede observar a simple vista, no se hicieron mediciones para analizar los pigmentos.

Tal parece que se utilizó el sistema de registro prehispánico para plasmar esta nueva imagen y el simbolismo que estaba detrás. La cruz cristiana está relacionada con el sacrificio de Cristo, pero a la vez, dicho sacrificio es un símbolo de la redención, de la salvación de la humanidad, de la nueva vida, por tanto también está vinculado con el renacimiento, con la fertilidad. Valores que estaban presentes, de otra manera, en el sistema de pensamiento mesoamericano y en el culto que se realizaba en la Ba'cuana, como se ha expuesto más arriba. Según las fuentes de los primeros tiempos de la Conquista, en los rituales que hacían los zapotecos, y concretamente en el istmo, se sacrificaban animales. ${ }^{34}$ Bastantes de las ofrendas representadas en Ba'cuana corresponden a animales, y es probable que se hayan sacrificado en los rituales de petición que se relacionaban con la pintura de esas imágenes. Por lo anterior, y al tener en cuenta que había ciertas similitudes en las ideas y valores de estos dos sistemas religiosos, no debe sorprender la representación de la cruz cristiana, símbolo de sacrificio, pero también de fertilidad, sobre un cuenco, de la misma manera que las ofrendas prehispánicas. Creo que se trataba de apropiarse e integrar los nuevos signos y simbolismos en su sistema religioso y en sus lugares sagrados, con sus recursos artísticos y expresivos.

Resulta muy interesante la solución plástica que llevaron a cabo para pintar la cruz como ofrenda, usando dos motivos prehispánicos anteriores, el cuenco y la cruz de brazos iguales que se unieron por medio del asa-canasta alargar uno de los brazos de la cruz. En general, se aprecia un intento de los zapotecos de los primeros tiempos coloniales de representar las nuevas ideas y símbolos mediante su sistema gráfico de comunicación y su estética, de aprehender lo nuevo a partir de lo conocido, de sus medios de expresión y su cultura. Esto se ha observado en otros casos de arte rupestre colonial en otras partes del mundo, en las primeras fases del contacto. ${ }^{35}$

34. Judith Francis Zeitlin, "Recordando a los reyes. El Lienzo de Guevea y el discurso histórico de la época colonial”, en Escritura zapoteca. 2500 años de historia, coord. Miguel Ángel Romero (México: Instituto Nacional de Antropología e Historia-Centro de Investigaciones y Estudios Superiores en Antropología Social/Porrúa, 2003), 300.

35. José Luis Martínez y Marco Antonio Arenas, "Iglesia en la piedra: representaciones rupestres y evangelización en los Andes del Sur", en La vitalidad de las voces indigenas: arte rupestre 


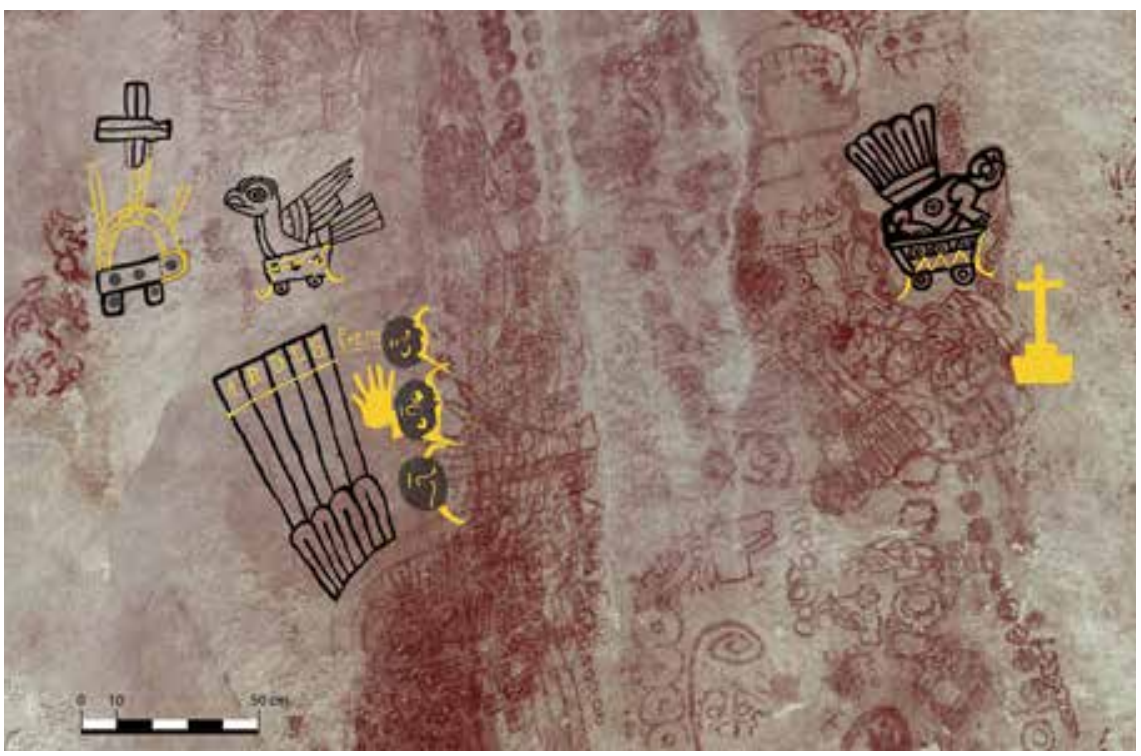

20. Dibujo de motivos coloniales del Conjunto i de la peńa-cueva del sitio Ba'cuana, sobre detalle de reconstrucción fotogramétrica. Reconstrucción fotogramétrica: Equipo de la Dra. Geneviève Lucet. Dibujo: José Moisés Cerero Arellano.

\section{Peña-cueva: siglos XVII y XVIII}

Tiempo más tarde, probablemente más de un siglo después, se volvió a pintar en esta especie de cueva (fig. 20), en una ocasión para añadir un nuevo motivo, y en las otras para intervenir motivos antiguos pero amalgamándolos con otros simbolismo nuevos e inesperados. El nuevo motivo ańadido es una cruz que se desplanta sobre un basamento de dos cuerpos (fig. 20). Tiene la forma de una cruz atrial, o una cruz en un humilladero. Está pintada rellenando todo su interior, en tinta plana. El color es amarillento. El contorno que presenta es un poco irregular. Es significativa la posición que ocupa en uno de los límites del gran conjunto central de imágenes del techo y se sobrepone en un área muy pequeña a un motivo prehispánico, por lo que parece que su reali-

del contacto y en sociedades coloniales, ed. Fernando Berrojalbiz (México: Universidad Nacional Autónoma de México-Instituto de Investigaciones Estéticas, 2015), 310 y 317; Sally K. May, Inés Domingo y Paul S. C. Taçon, "Arte rupestre de contacto: la versión indígena de los encuentros interculturales de la Tierra de Arnhem (Australia)", en La vitalidad de las voces indígenas, 99. 


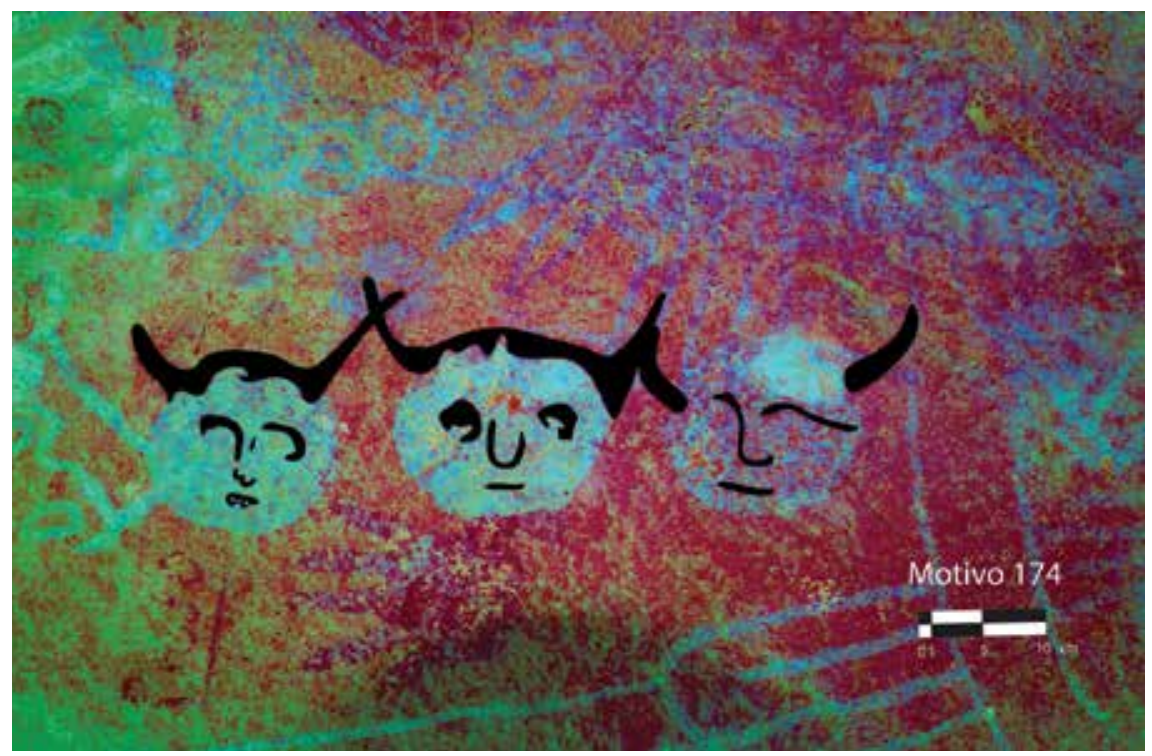

2I. Dibujo de los tres diablitos de la peña-cueva sobre foto con tratamiento mediante el programa Image J y el plug in Dstretch. Tratamiento: Fernando Berrojalbiz. Dibujo: José Moisés Cerero Arellano.

zación no tenía como objeto principal tapar, ocultar o negar los motivos prehispánicos, o por lo menos no se demuestra un gran esfuerzo en ello. Más que cristianizar el lugar rechazando las imágenes prehispánicas, parece el añadido de una imagen más al complejo entramado visual del techo, al agregar nuevos simbolismos, en este caso la cruz, que tiene esa connotación de renovación y fertilidad, al mismo tiempo que sacrificio, ideas que tienen coincidencias con lo que expresaban los motivos prehispánicos.

En el centro del conjunto, el añadido de ciertos elementos a tres motivos antiguos me permitió tirar del hilo de la posible explicación de una serie de temas antiguos intervenidos. Dentro de la aglomeración de pinturas prehispánicas en esta zona existe una asociación de un numeral, el tres, con un signo, garra de jaguar, como un ejemplo más de este tipo de combinaciones de motivos que abundan en el sitio para indicar el nombre de un día o de una persona. En este caso particular, los tres puntos del numeral están pintados en tinta plana. Durante el virreinato se intervinieron estos tres círculos con otro pigmento de un color entre beige y naranja (fig. 2I). Se tomaron estos tres círcu- 
DOI: https://doi.org/10.22201/iie.18703062e.2020.116.2718

los como si fueran rostros antropomorfos redondos y con unos pocos trazos se pintaron ojos, nariz, boca y unos cuernos.

Pegado al círculo central se halla el motivo de una mano realizada impregnando la mano del pintor en pigmento y presionando la roca con la palma abierta (fig. 20). Se trata de una mano derecha y los dedos apuntan hacia el interior de la cueva. El color es similar a los motivos de los círculos intervenidos como rostros con cuernos. Entre la mano y el círculo, hay un elemento que los une hecho con el mismo pigmento, que tiene forma de rectángulo irregular, como un moño.

Arriba de la mano y a un lado del círculo intervenido superior se halla una palabra escrita con alfabeto latino, del mismo color que las intervenciones en los círculos y la mano. Se trata de la palabra preso, subrayada (fig. 20). Al lado sur se encuentra un motivo prehispánico, una especie de atado de plumas. Éste fue intervenido en su parte superior con pintura del mismo color que los motivos anteriores. Se hizo un trazo que atravesó transversalmente las líneas verticales de las plumas formando cinco casillas. Encima de este trazo y en cada una de las casillas se escribió una letra en mayúsculas que forman una palabra en latín: ABDEs. El verbo en latín abdere puede significar muchas cosas: ocultarse, esconder, hacer desaparecer, proteger, resguardarse. En este caso está en segunda persona del singular del futuro de indicativo, que se traduciría aproximadamente como: ocultarás..$^{36}$ Debido al tipo de letra y a que se trata sólo de dos palabras y no de un texto más amplio, es difícil atribuir una cronología por su estilo a estas palabras, por lo que pueden corresponder tanto al siglo XVII como al XviII. ${ }^{37}$

Por último, quedan dos intervenciones similares de este grupo de motivos coloniales. Encima del atado de plumas, de la palabra preso y de los tres círculos se halla un motivo prehispánico que es una convención común para representar una ofrenda. Consiste en la imagen de un cuenco cerámico trípode (aunque sólo se ven dos de los soportes por la vista de perfil), encima del cual se halla el motivo de un ave, posiblemente un loro. En época colonial se intervino este motivo con un pigmento de color similar a los anteriores (figs. 7 y 20). En la unión de la base del cuenco con las paredes se pintaron sendas líneas curvas hacia el exterior, hacia el cuadrante inferior, en forma de gancho. Parece que trataron de dibujar faldones al cuenco a la manera de un carro. De

36. Agradezco la información sobre el término abdes a Iván Escamilla.

37 Comunicación personal con Franziska Neff. 


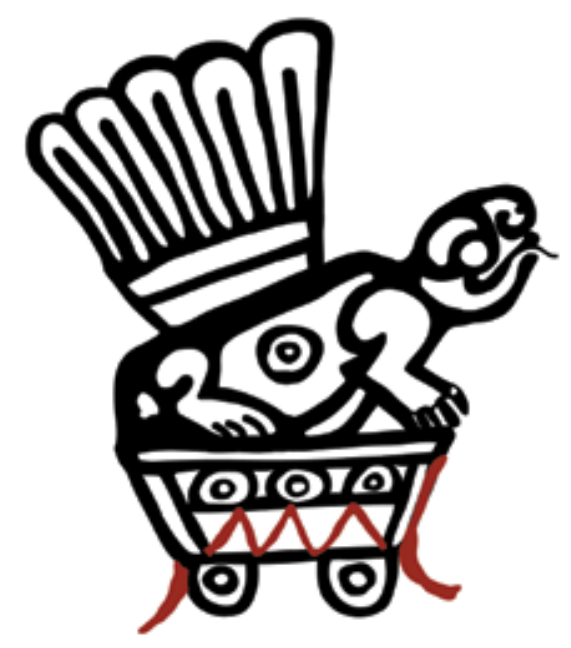

22. Dibujo del motivo del cuenco con la rana encima, intervenido en época colonial de la peña-cueva. Dibujo: Fernando Berrojalbiz.

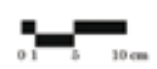

estos trazos la intervención continúa con una línea quebrada que atraviesa la vasija. El otro elemento intervenido se halla un poco alejado del grupo, junto a la cruz tipo atrial. El motivo prehispánico que sirvió de base también es una ofrenda. Consta del cuenco con sus dos soportes, encima del cual se pintó lo que parece ser una rana o sapo (fig. 22). Destaca que sobre su espalda se despliega un gran adorno de plumas. Al igual que en el motivo anterior, y con el mismo color, se dibujaron unos trazos a la manera de unos faldones y una línea quebrada que atraviesa el cuerpo de la vasija, formando una serie de triángulos contiguos. En ambos casos los trazos son gruesos, de factura tosca e irregular.

\section{Conjuro de santa Marta}

Cuando inicié el análisis de estas imágenes me llamaron mucho la atención estas intervenciones en los tres círculos, dibujando unos rostros con cuernos. Una de las primeras relaciones que se puede establecer es con imágenes del diablo. Por otra parte, la palabra en latín abdes, con su significado, ocultarás, unido a las imágenes de diablos me hicieron pensar en cultos no ortodoxos re- 
lacionados con la religión cristiana,$^{38}$ prohibidos y por tanto que era necesario mantener en secreto. Investigué sobre prácticas heréticas y cultos diabólicos y encontré un conjuro que tuvo una amplia distribución en la Nueva España, con variaciones abundantes e interesantes, el cual creo que está relacionado con las imágenes de este grupo. Se trata del conjuro de santa Marta, del cual incluyo una de las versiones:

Marta, Marta,

no la dina ni la santa,

la que los polvos lebanta,

la que las palomas espanta,

la que entrando en el Monte Taburón,

con tres cabras negras encontró,

tres cucharas de cacha negra cojió,

tres negros quesos quajó,

en tres platos negros los hechó,

con tres cuchillos de cachas negras los cortó,

con tres diablos negros los conjuró,

y así te conjuro yo.

Yo te conjuro con el diablo de la ciçaña.

Yo te conjuro con el diablo de la maraña.

Yo te conjuro con diablo de la guerra.

Al tiangues los sacó Fulano.

Los conpró y a su casa los llebó,

entre Él y Fulano y Sutano los comió.

Comiéndolos tengan el gusto y el contento que tienen.

El perro y el gato debajo de la mesa:

estén siempre con ciçaña y maraña y guerra. ${ }^{39}$

38. Es interesante recordar que la liturgia católica en esa época se realizaba mayormente en latín.

39. Archivo General de la Nación, Puebla, Ramo: Inquisición, I629, vol. 366, exp. I4, fol. 223v.; Araceli Campos Moreno, Oraciones, ensalmos y conjuros mágicos del archivo inquisitorial de la Nueva España (I600-I630) (México: El Colegio de México, 200I), I24. 
Creo que este conjuro está relacionado con estas imágenes ya que la referencia a tres diablos es muy clara, y también resalta la importancia del número tres, que se repite con abundancia en esta versión del conjuro, pero también aparece en otras versiones del mismo..$^{\circ}$ Además, la palabra preso aparece en otra versión de este conjuro, con la idea de que santa Marta o el diablo pueden liberar a presos. ${ }^{41}$

Este conjuro surgió a finales de la época medieval en España, y luego se trasladó a la Nueva España. ${ }^{42}$ La relación de santa Marta con el diablo procede de la leyenda de la vida de esta santa. Marta, hermana de María Magdalena y de Lázaro, después de la muerte de Jesucristo, expulsada de Betania junto con sus hermanos, llega a Marsella. Se separa de sus hermanos y llega a un poblado llamado Tarascón, el cual estaba asolado por un monstruo, denominado Tarasca. Fue al bosque a su encuentro, lo dominó y lo llevó domesticado al poblado, donde los pobladores lo mataron. Al domesticar al dragón, fiera o serpiente (metafóricamente podría ser el demonio), Marta domina y acaba con el mal y se convierte en heroína del cristianismo. Su veneración se extendió por países cristianos en Europa, sobre todo en España, donde arraigó con gran fuerza en Andalucía, y de la Península llegó a la Nueva España. Como en todas las leyendas, la cultura popular usó y modificó los atributos concedidos a la santa. Uno de los aspectos que más llamó la atención en la cultura popular fue su capacidad de dominar, en principio para dominar el mal. Sin embargo en algunas derivaciones de esta cultura popular adquirió connotaciones negativas e incluso eróticas. Así se pueden encontrar conjuros que diferencian entre invocar a Marta buena o Marta mala; en estos últimos casos es donde se la relaciona con los diablos, como en la versión incluida más arriba, y su capacidad de dominarlos como dominó a la Tarasca, la metáfora del diablo, y que trabajen para ella. ${ }^{43}$

En los casos estudiados en la Nueva España los propósitos de realizar el conjuro se relacionan con peticiones amorosas, ${ }^{44}$ sometimiento o apaciguamiento del marido en casos de violencia doméstica, y la obtención de fuerza física y

40. Campos Moreno, Oraciones, ensalmos y conjuros mágicos, I80.

4I. Campos Moreno, Oraciones, ensalmos y conjuros mágicos, 179.

42. Campos Moreno, Oraciones, ensalmos y conjuros mágicos, I79.

43. Noemí Quezada Ramírez, "Santa Marta en la tradición popular", Anales de Antropología, núm. X (1973): 228; Campos Moreno, Oraciones, ensalmos y conjuros mágicos, IOO-IO2, I23, I24.

44. "su importancia en México como una de las santas más invocadas en el periodo colonial y en nuestros días para fines amorosos". Véase Noemí Quezada Ramírez, "Oraciones mágicas en la colonia”, Anales de Antropología, núm. XI (1974): 221. 
DOI: https://doi.org/10.22201/iie.18703062e.2020.116.2718

salud para enfermos. ${ }^{45}$ Por otra parte, varios conjuros se utilizaron para liberar prisioneros, y aunque en los casos estudiados en la Nueva España del conjuro de Santa Marta no aparece estrictamente este propósito, en una de las versiones, como he señalado antes, se menciona esta capacidad.

En la parte superior de los tres diablitos, la mano y la palabra preso está el motivo de un loro sobre un cuenco que fue intervenido, queriendo dar la idea de un carro. Lo mismo ocurre con la intervención del motivo de la rana sobre el cuenco. Al investigar sobre el personaje de santa Marta y la leyenda alrededor de ella descubrí que estaba relacionada con un elemento que era muy importante y significativo en la época colonial en la fiesta del Corpus Christi, una de las principales fiestas. En éstas desde el siglo Xvi se organizaba una gran procesión en las ciudades novohispanas, en la que desfilaban las diferentes autoridades y sectores de la sociedad e incluía pasos procesionales con imágenes religiosas, como el Corpus Christi, y carros procesionales de diferente tipo, en algunos de los cuales se representaban comedias. ${ }^{46} \mathrm{Sin}$ embargo, lo que más me interesa destacar es que la procesión estaba precedida por la Tarasca, el ser monstruoso y diabólico que es dominado por santa Marta. En esta procesión, siguiendo los simbolismos de la leyenda alrededor de la santa, la Tarasca representaba al mal y al pecado derrotados por el Santísimo Sacramento (en sustitución de santa Marta, pero su leyenda en el fondo era el triunfo de Cristo sobre el mal), simbolizaba el triunfo de la eucaristía. ${ }^{47}$

Pero ¿cómo se representaba la Tarasca? Como un animal fantástico, entre dragón y serpiente, confeccionado con madera, pasta y tela. En las imágenes conservadas de aquella época de dicho ser se le plasma con una piel llena de escamas o relacionada con un ser anfibio, con alas y plumas como un ave, que era transportada sobre un soporte rectangular que llevaba andas o un tipo de carro (fig. 23). ${ }^{8}$ En un cuadro de Manuel de Arellano, Traslado de la imagen y estreno del santuario de Guadalupe, de I709, se puede observar en el lado

45. Campos Moreno, Oraciones, ensalmos y conjuros mágicos, IO2.

46. Nelly Sigaut, "La fiesta de Corpus Christi y la formación de los sistemas visuales", en Memoria del IV Encuentro Internacional sobre Barroco. La Fiesta, ed. Norma Campos Vera (La Paz, Bolivia: Unión Latina, Griso/Universidad de Navarra/Embajada Real de los Países Bajos, 20II), I24. 47. Sigaut, "La fiesta de Corpus Christi y la formación de los sistemas visuales", I24.

48. Véase Tarasca para la procesión del Corpus de 1744, Madrid, en http://www.memoriademadrid.es/buscador.php?accion=VerFicha\&id=42935, consultado en marzo de 20I8, 


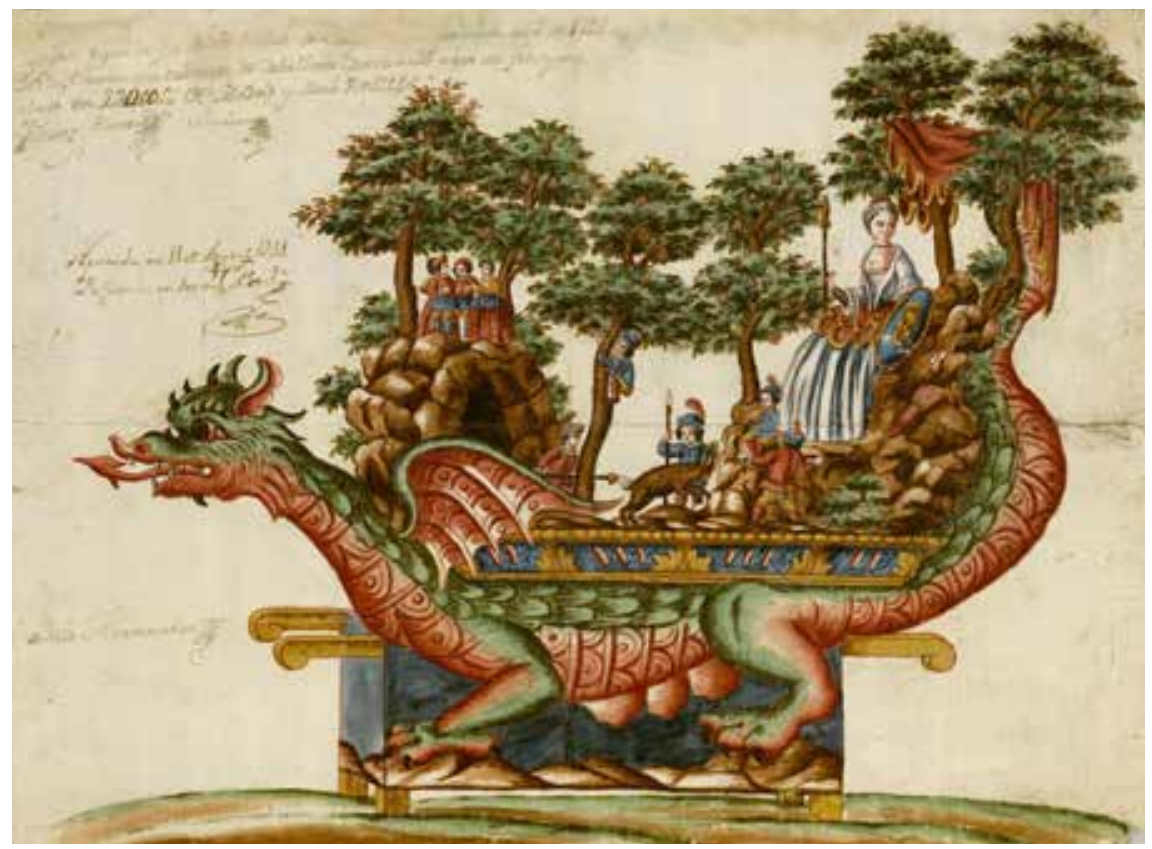

23. José María Bernáldez, Tarasca para la procesión del Corpus de I744, 4I x $53 \mathrm{~cm}$. Ayuntamiento de Madrid, Archivo Villa. Biblioteca digital memoria de Madrid.

Sig. 2-2O4-I3. CC. BY-NC 2.5 ES.

izquierdo de la pintura, en el atrio del santuario, a la Tarasca con sus alas a la que se le transportaba sobre un soporte con ruedas (fig. 24 ). ${ }^{49}$

Si se observan los dos motivos, el loro y la rana sobre el cuenco, se puede apreciar que tienen muchas características en común con la Tarasca. En primer lugar, están encima de un objeto rectangular, el cuenco con los dos soportes, que tal como está representado da la idea de un carro con ruedas. La intervención realizada parece representar unos faldones. Creo que se están mezclando en una sola imagen elementos que suelen aparecer en la procesión de Corpus Christi, pero en dos objetos diferentes: el carro con ruedas que transporta a la Tarasca por un lado, y los faldones de los pasos procesionales religiosos. Pero en ambos pertenecen a soportes que portan númenes o entidades extraordinarias

49. Este cuadro se encuentra en una colección particular. Citado en Nelly Sigaut, "La fiesta de Corpus Christi”, I34. 
de gran poder, elementos principales en la procesión. En el caso del loro, vimos que uno de los elementos de la Tarasca son las alas, que en ocasiones son de gran tamańo y enfatizan este carácter aviario de la Tarasca. Pero en el otro caso es más contundente la similitud, ya que está representado un anfibio, una rana o sapo, que coincide con el tipo de piel y el cuerpo de la Tarasca en la mayoría de sus representaciones y, además, presenta las plumas como si fueran un ala de ave, uniendo dos de los elementos principales que la caracterizan (fig. 22).

Otro aspecto de las procesiones del Corpus Christi que puede reforzar la identificación de estos motivos con la Tarasca, es que en dichas procesiones, tanto en ciudades españolas como novohispanas, ésta aparecía acompañada de varios diablitos, que la rodeaban y bailaban con ella, como se puede observar en el cuadro novohispano de 1709, citado más arriba (fig. 24). A esto se añade que las comedias surgieron y fueron una parte muy importante de la fiesta del Corpus en la Nueva España. En éstas, uno de los personajes más recurrentes era don Cojín, como encarnación del demonio. ${ }^{50}$

Es interesante señalar en este punto que la importancia de la fiesta en la Nueva España radicaba en su capital visual por la acumulación de metáforas, alegorías e imágenes cristianas de larga tradición occidental, mezcladas con manifestaciones propias de una sociedad pluriétnica y pluricultural como lo fue México. Tenía un gran potencial didáctico, proveía herramientas privilegiadas para activar la devoción, ${ }^{5 \mathrm{I}}$ pero también podía favorecer otra clase de desarrollos no tan deseados o previstos, que promovían relaciones o vinculaciones con prácticas heréticas o demoniacas, el lado oscuro del cristianismo, la otra cara de la misma moneda. ${ }^{52}$

Por tanto, opino que todos los motivos en este grupo están relacionados con la leyenda de santa Marta y son aspectos que aparecen o son referidos en el conjuro. La palabra abdes, vocablo en latín, idioma relacionado con la liturgia católica, creo que trata de enfatizar el mantenimiento de estas prácticas,

50. Sigaut, "La fiesta de Corpus Christi", I29.

51. Sigaut, "La fiesta de Corpus Christi", I23.

52. Desde 2013 en el sitio Ba'cuana se desató un problema de vandalismo sobre la roca que tiene el espacio inferior, la cueva. Consistían en pintas de pasajes de la Biblia o los evangelios. Después de un trabajo de un año en los pueblos aledaños, una alumna del proyecto supo que grupos evangelistas que viven relativamente cerca del sitio hicieron esas pintas no porque consideraban a las pinturas prehispánicas como algo demoniaco, sino porque decían que sabían que en la cueva todavía se hacían cultos satánicos. Comunicación personal de Asarel Polo, 6 de marzo de 2018. 


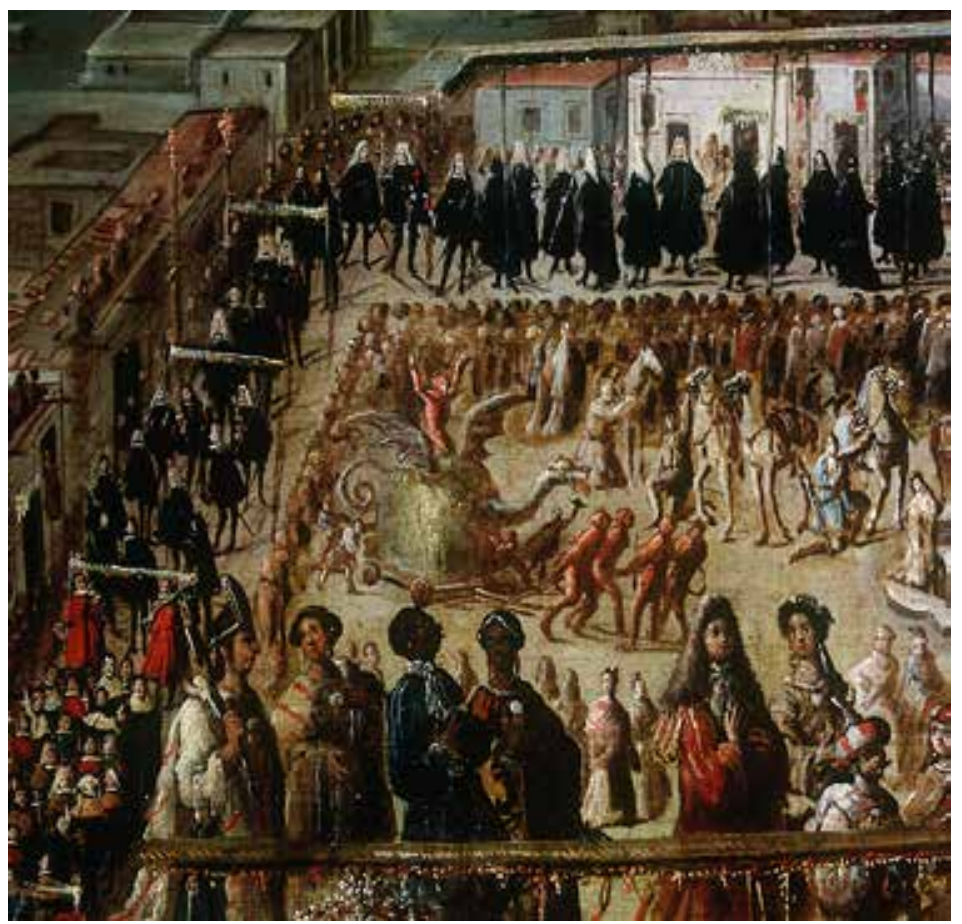

24. Manuel de Arellano, Traslado de la imagen y estreno del Santuario de Guadalupe, detalle, óleo sobre tela. Colección particular. Foto: Ernesto Peñaloza, I999. Archivo Fotográfico Manuel Toussaint, IIE-UnAM.

el conjuro y su ritual, en el ámbito de lo secreto y oculto. No es extrańo que aparezcan términos en latín en conjuros en la Nueva España en el siglo XviI. ${ }^{53}$

Un aspecto interesante de este grupo central del conjunto I es la relación de tales motivos con los anteriores prehispánicos. En primer lugar, es necesario recordar que las expresiones prehispánicas tenían una relación muy estrecha con la oralidad. Algunos autores señalan que los códices en época prehispánica servían como base o referencia a unos especialistas que narraban las historias de los linajes o algunos mitos en eventos o rituales destacados al tiempo que

53. David Tavárez, Las guerras invisibles: devociones indígenas, disciplina y disidencia en el México colonial (Oaxaca: Universidad Autónoma Benito Juárez de Oaxaca, 2012), 233, 239. 
DOI: https://doi.org/10.22201/iie.18703062e.2020.116.2718

los estaban leyendo. ${ }^{54}$ La narración oral era muy importante. En el caso de los conjuros, los estudios que se han hecho sobre ellos tanto en la Nueva España como en la Península Ibérica señalan la importancia de pronunciar la palabra, de decir el conjuro, que desataba unos poderes antes no presentes. ${ }^{5}$ Durante la colonia, en partes de Oaxaca de habla zapoteca, existen informaciones de que el acto retórico de interpretar un texto ritual oralmente era muy importante. ${ }^{6}$ Quizá se pintaron estas imágenes relacionadas con el conjuro, intentando establecer la misma vinculación entre las expresiones pintadas prehispánicas y los eventos de narración oral, como una base o referencia para estos conjuros.

Por otra parte, a diferencia de las imágenes coloniales que he comentado hasta ahora, que se situaban en los márgenes de conjuntos posclásicos o en paneles adyacentes, en este grupo están entre motivos prehispánicos o interviniendo y modificando alguno de ellos. Creo que la intención no es sólo añadir en el sentido de acumular nuevos simbolismos, sino la reinterpretación de imágenes según un nuevo discurso visual, otra estética, otros simbolismos, que se plasman en la obra interviniendo o pintando nuevos pero sin borrar, tapar o negar las imágenes antiguas, más bien con el propósito de fusionarse con ellas. Estos artistas virreinales reconocen el valor de estas antiguas imágenes, su poder, su carácter sagrado, aunque posiblemente no sepan de manera precisa sus significados antiguos. Esto es comparable con lo que se ha interpretado para sitios rupestres coloniales en México, incluso fuera del área mesoamericana. ${ }^{57}$ Las nuevas ideas e imágenes que están representando quieren vincularlas, entretejerlas con las antiguas. Utilizando un símil extraído del arte textil, es como si quisieran entrelazar nuevos motivos en la trama, pero tejiendo sobre la misma urdimbre, de manera que siga siendo un mismo tejido.

\section{Atribución temporal de las imágenes del conjuro de santa Marta}

Los estudios que se han hecho sobre los conjuros en época colonial, principalmente basados en documentos de procesos de la Inquisición, indican que el

54. Pablo Escalante, Los códices mesoamericanos antes y después de la Conquista (México: Fondo de Cultura Económica, 20I0), I5.

55. Quezada Ramírez, "Oraciones mágicas en la colonia", I43.

56. Tavárez, Las guerras invisibles, 283.

57. Sandra Cruz Flores, "Resignificación y estrategias de conservación integral del patrimonio rupestre: el cañón de La Pintada, Sonora”, en La vitalidad de las voces indígenas, 222. 
conjuro de santa Marta fue bastante popular durante el siglo Xvi y la primera mitad del siglo XVII, pero después ya no aparece en los documentos inquisitoriales..$^{58}$ Esto no quiere decir que desapareciera el conjuro o la importancia de santa Marta en el imaginario popular, ya que se ha conservado hasta nuestros días.99 Sin embargo, parece que la popularidad que tuvo en los siglos XVI y XVII decayó bastante posteriormente.

Puede ser muy útil comparar la evolución que tuvo este conjuro con el personaje de la Tarasca en las fiestas novohispanas. Al parecer, dicho personaje tuvo una evolución parecida al desarrollo de la fiesta del Corpus que se fue haciendo más grande y compleja en la segunda mitad del siglo XVI y primera del XVII, con la aparición de carros triunfales y las comedias. Los carros procesionales y la Tarasca tuvieron tanto éxito que empezaron a aparecer en otras fiestas. ${ }^{60}$ Sin embargo, los estudios indican que en la fiesta del Corpus, en la Ciudad de México, durante el siglo Xvir las comedias disminuyen y desde I630 no aparecen los carros procesionales, y posiblemente las comedias. ${ }^{61} \mathrm{La}$ Tarasca con seguridad sufrió la misma suerte en la fiesta del Corpus, pero siguió apareciendo en otras fiestas, por lo menos hasta principios del siglo XVIII, ${ }^{62}$ aunque quizá se perdió parte de la importancia del papel que desarrollaba en la procesión del Corpus. Como dice Nelly Sigaut sobre la fiesta de Corpus Christi: "fiesta espléndida que había sido el Corpus en los primeros dos siglos de administración hispana." ${ }_{3}$

Es interesante constatar el paralelismo de la evolución del conjuro de santa Marta y la Tarasca en la fiesta del Corpus, ya que ambos parecen seguir el mismo desarrollo temporal, teniendo un auge en el siglo XVI y primera mitad del XVII, y perdiendo importancia en la segunda mitad del XVII y en el XVIII. $\mathrm{Si}$ a esto se añade el tipo de letras de las palabras preso y abdes asociadas, que más parecen corresponder a los siglos XVII y XVIII, a mi parecer la ejecución

58. Quezada Ramírez, "Santa Marta en la tradición popular”, 228; María Águeda Méndez, Ricardo Camarena Castellanos, Fernando Delmar y Ana María Morales, Catálogo de textos marginados novohispanos. Inquisición: siglo XVII (México: Archivo General de la Nación/El Colegio de México/Fondo Nacional para la Cultura y las Artes, 1997).

59. Quezada Ramírez, "Santa Marta en la tradición popular", 221.

6o. Sigaut, "La fiesta de Corpus Christi", I3I.

6I. Sigaut, "La fiesta de Corpus Christi", I32.

62. El cuadro de Arellano es una evidencia de que a principios del siglo XviI aparecía la Tarasca en fiestas importantes.

63. Sigaut, "La fiesta de Corpus Christi", I26. 
DOI: https://doi.org/10.22201/iie.18703062e.2020.116.2718

$2 \mathrm{I} 2$

FERNANDO BERROJALBIZ

de estas imágenes data del siglo XviI, época en la que tanto el conjuro como la Tarasca eran más populares y tenían más presencia, o como muy tarde de principios del siglo XviII.

\section{Análisis de pigmentos}

El análisis de los pigmentos de los motivos coloniales del conjunto I muestra, en general, una gran diferencia respecto de los prehispánicos, en el contenido de hierro. En estos últimos es significativamente más abundante. Lo que distingue a los coloniales es la escasa presencia o la ausencia del hierro. ${ }^{64}$ Esta pequeña diferencia dentro de los motivos coloniales de este grupo podría indicar dos etapas de ejecución diferentes, pero la distribución de estos motivos en estos dos conjuntos es muy azarosa, no se observa un patrón ni por la iconografía ni por la posición ni por el estilo. Debido a ello, por el momento, no puedo distinguir una secuencia clara de ejecución dentro de este grupo, por lo cual todos los motivos serán considerados contemporáneos. En cuanto a la presencia de otros elementos químicos en los análisis de estos motivos coloniales, éstos no muestran una tendencia clara que haga pensar que eran parte del pigmento.

\section{Algunos aspectos del contexto histórico}

En este apartado reflexiono acerca de quiénes pudieron realizar estas pinturas y cómo adquirieron esos conocimientos, esas referencias.

El sitio de arte rupestre Ba'cuana se halla en los límites de dos pueblos: Ixtaltepec e Ixtepec. Ambos poblados se mencionan en varios documentos del

64. En un trabajo de análisis de pigmentos, elaborado en un sitio en Chile con las mismas técnicas, se descubrió una diferencia similar entre pinturas con mucho contenido de hierro y otras con muy poco contenido, lo que sugiere que se trata de pigmentos diferentes, basados en materiales distintos, seguramente silicatos de aluminio con alguna presencia de contenido de hierro. Marcela Sepúlveda, Sebastián Gutiérrez, José Cárcamo, Adrián Oyaneder, Daniela Valenzuela, Indira Montt y Calogero M. Santoro, "In Situ X-Ray Fluorescence Analysis of Rock Art Paintings along The Coast and Valleys of The Atacama Desert, Northern Chile", Journal of the Chilean Chemical Society 60, núm. I (2015): 2824. 
siglo XVI, como en las Relaciones geográficas de Antequera, de 1580. ${ }^{65}$ Lo que no podemos saber con certeza es si eran comunidades que ya existían como tales antes de los españoles o su creación responde a la política de congregaciones que tuvo lugar en la década de los 40 del siglo Xvi en las que la población dispersa se reunió en asentamientos más compactos. ${ }^{66} \mathrm{~A}$ principios del siglo XVII ya aparecen en documentos con los nombres de Santa María Asunción Ixtaltepec y San Jerónimo Ixtepec. ${ }^{67}$

También es interesante conocer cómo había sido la composición de la población en el istmo desde la Conquista. Es de destacar que la población española fue escasa hasta la segunda mitad del siglo XviII. En esto influyó, entre otras razones, que antes de 1580 la entrada de españoles había sido restringida por haber sido la mayor parte de estas tierras parte del marquesado del Valle. Además, hay que señalar que después de más de un siglo de constantes epidemias, hacia mediados del siglo XviI, la población indígena se encontraba en sus niveles más bajos. ${ }^{68}$

En la segunda mitad del xviII empezó un ascenso de la población, que se vio reflejado también en el aumento de españoles y de mulatos y negros. En los pueblos de Ixtepec e Ixtaltepec también ocurre este mismo proceso de manera que hasta la segunda mitad del xviı es cuando se encuentra una población considerable de habitantes no indígenas, sobre todo de mulatos. ${ }^{69}$

En cuanto al sistema religioso de los habitantes de estas poblaciones a finales del siglo XVI ocurren cambios significativos: se incorporan santos católicos y vírgenes, se gastan considerables cantidades en el rito católico, velas, ornamentos y retablos, lo que puede ser una señal, según Romero Frizzi, de que la religión europea fue reinterpretada y adaptada a su mentalidad: se estaba produciendo un desarrollo cultural nuevo. ${ }^{70}$

65. René Acuña, comp., Relaciones geográficas del siglo XVI. Antequera. 2 vols. (México: Universidad Nacional Autónoma de México-Instituto de Investigaciones Antropológicas, 1984), 310.

66. Laura Machuca Gallegos, El comercio de sal y redes de poder en Tehuantepec durante la época colonial (México: Publicaciones de la Casa Chata/Centro de Investigaciones y Estudios Superiores en Antropología Social, 2007), 48.

67. Laura Machuca Gallegos, "Haremos Tehuantepec". Una historia colonial (siglos XVI-XVIII) (Oaxaca: Consejo Nacional para la Cultura y las Artes/Secretaría de Cultura del Gobierno del Estado de Oaxaca/Centro de Investigaciones y Estudios Superiores en Antropología Social, 2008), 59.

68. María de los Ángeles Romero Frizzi, El sol y la cruz. Los pueblos indios de Oaxaca colonial (México: Instituto Nacional Indigenista/Centro de Investigaciones y Estudios Superiores en Antropología Social, 1996), 197.

69. Machuca Gallegos, El comercio de sal y redes de poder en Tehuantepec, 63.

70. Romero Frizzi, El soly la cruz. Los pueblos indios de Oaxaca colonial, II6 y II7. 
Los conventos dominicos de Tehuantepec y de Jalapa del Marqués, las dos instituciones religiosas cristianas más importantes de la región, se acabaron de construir en la segunda mitad del siglo xvi y eran los únicos lugares donde había frailes en la región hacia el final del siglo. ${ }^{71}$ Así y todo, tuvieron una influencia muy importante en la población, una estrategia que ejercieron los dominicos para tener a los indios de su parte en sus luchas de poder, sobre todo económico. ${ }^{72}$ No he podido constatar las fechas de construcción de las iglesias tanto de Ixtepec como de Ixtaltepec, pero deben haberse erigido en el siglo XVII, ya que en el XviII se menciona a los dominicos al frente de las iglesias de estos pueblos, como se puede ver en los libros parroquiales. ${ }^{73}$

En cuanto a las imágenes pintadas en el siglo XVI, Tehuantepec, en el último siglo antes de 1530 , fue el centro de la unidad política zapoteca prehispánica más importante del momento, con centros urbanos, con una organización social jerarquizada y compleja, donde es bastante probable que se elaboraran documentos pictográficos. ${ }^{74}$ Conozco los sitios de arte rupestre pintados en ese periodo. La calidad de los mismos indica que había especialistas en la realización de estas pictografías, quienes, a la llegada de los frailes, pudieron haber sido instruidos en las nuevas ideas religiosas, la nueva escritura, las nuevas imágenes y los simbolismos. ${ }^{75}$ Ellos pudieron combinar y reelaborar las nuevas imágenes con las técnicas y sistemas de representación antiguos, por lo que pudieron ser los artistas de los motivos atribuidos al siglo Xvi de la Ba'cuana.

En los siglos XVII y XVIII la presencia de la Iglesia católica y especialmente la orden de los dominicos estaba ya bien asentada en la región. Los dos grandes centros eclesiásticos eran los conventos de Jalapa del Marqués y de Tehuantepec. Existían iglesias en los pueblos como Ixtaltepec e Ixtepec que eran atendidas

71. Machuca Gallegos, "Haremos Tehuantepec", 27.

72. Machuca Gallegos, "Haremos Tehuantepec", 29.

73. Roberto Zárate Morán y Raúl Mena Gallegos, San Jerónimo. Taniqueza. Arqueología, historia e identidad de un pueblo zapoteco del Istmo de Tehuantepec (Oaxaca de Juárez: Instituto Nacional de Antropología e Historia-Centro Oaxaca/Fuerza Eólica del Istmo, 20Io), 57.

74. Judith Francis Zeitlin, "Recordando a los reyes. El Lienzo de Guevea y el discurso histórico de la época colonial”, en Escritura zapoteca. 2500 años de historia, coord. Miguel Ángel Romero (México: Centro de Investigaciones y Estudios Superiores en Antropología Social/ Instituto Nacional de Antropología e Historia/ Porrúa, 2003), $265-267$.

75. Se conocen unos pocos documentos coloniales de Tehuantepec, de quejas de unos indios, donde se pintan unas escenas de abusos con elementos de estilo de los códices mixtecas y elementos europeos, aunque por la falta de habilidad y conocimiento de los glifos se piensa que fue la obra de un comunero y no de un especialista, véase Francis Zeitlin, "Recordando a los reyes", 278. 
por dominicos. La evangelización estaba en marcha, por lo que el conocimiento de la Biblia, de las fiestas religiosas católicas, de las vidas de santos, de la doctrina católica en general podía ser bastante común. En esta evangelización los libros religiosos con grabados tendrían una gran importancia. A esto se añade que desde el siglo XviI, como en Ixtaltepec, en casi todos los pueblos se habían creado cofradías. ${ }^{76}$ Por ello no es difícil pensar que pudiera haber en estos pueblos indígenas personas que tuvieran un buen dominio de la iconografía católica y que a la vez les quedaran algunos conocimientos de la antigua cultura de sus antepasados, de su tradición pictórica, como para poder realizar la pintura del Cristo crucificado y el personaje arrodillado en el santuario de Bàcuana. En este punto quisiera traer a colación las informaciones sobre los juicios de idolatría que se produjeron en el pueblo de Sola de Vega, en las estribaciones de la Sierra Madre del Sur —al sur de los valles centrales de Oaxaca- a mediados del siglo XviI, y que pudo tener un contexto de evangelización parecido al que existió en Ixtepec e Ixtaltepec en aquella época. Lo que quiero resaltar es la calidad de instrucción de uno de los más importantes especialistas rituales que fue procesado: educado en la iglesia de Sola, había sido maestro cantor, escribano y regidor. Sabía leer y escribir y también hablaba náhuatl. ${ }^{77}$

Lo que resulta un poco más difícil de explicar son las líneas escritas bajo las imágenes. Por la posible transcripción de las pocas palabras visibles tales líneas aparentan ser un intento de aprobación o certificación de estas imágenes por autoridades, civiles o eclesiásticas novohispanas. Sin embargo, además de que hasta el momento no se han encontrado documentos inquisitoriales referentes a Ba'cuana, al revisar estudios de la persecución de idolatrías en Oaxaca, ${ }^{78}$ resulta poco creíble que las autoridades dedicadas a llevar casos de idolatrías hayan "aprobado" o "certificado" estas imágenes rodeadas por motivos prehispánicos en un lugar sagrado indígena. De haber sido objeto de un proceso por idolatría se habrían destruidas todas.

La hipótesis que propongo es que estas pinturas hayan sido objeto de una negociación local entre los frailes dominicos y la población indígena para cristianizar el lugar, pero sin destruir las expresiones prehispánicas. Las líneas escritas debajo de las imágenes se pudieron incluir para dar la impresión a la población de que esa "aprobación" tenía todos los elementos de un verdadero

76. Machuca Gallegos, "Haremos Tehuantepec", 133.

77. Tavárez, Las guerras invisibles, 208.

78. Tavárez, Las guerras invisibles, 23-26. 
acto oficial de autoridades novohispanas. En este sentido, los zapotecos tenían una larga tradición respecto de la importancia, incluso sagrada, de la escritura.

La evangelización y todo el arsenal de ideas, imágenes, prácticas y vivencias no llegó sola, vino acompańada de la otra cara de la moneda de la religión cristiana, las ideas, prácticas y vivencias no ortodoxas, heréticas y demoniacas. Si existían indígenas con buenos conocimientos de la doctrina y la iconografía cristiana y de la escritura en alfabeto latino, también es posible que hubiera personas en estas comunidades, indígenas, mulatos o mestizos (recordemos que la proporción de españoles o blancos en estas comunidades fue muy pequeña hasta mediados del siglo XVIII ${ }^{79}$ que tuvieran conocimiento de la parte oscura del cristianismo. Dichos saberes llegaron por otros canales. Esta zona del istmo era muy transitada por su ubicación estratégica; gran parte del comercio hacia Chiapas y hacia Centroamérica pasaba por aquí. Otro camino importante era el transístmico que conectaba con el Atlántico y con Coatzacoalcos. Por último el camino que unía esta región con Oaxaca y el altiplano. No se trataba de una zona aislada o poco transitada. ${ }^{80}$ Por tanto, los conjuros y prácticas diabólicas que llegaban al centro de la Nueva España o a las costas veracruzanas no tardarían en llegar al istmo.

Por otra parte, se tiene informaciones en actas de cabildo de la existencia de la Tarasca en las procesiones del Corpus en la ciudad de Oaxaca en época colonial, aunque era referida no con ese nombre sino como el monstruo ${ }^{8 \mathrm{I}}$ por lo que no sería difícil que las informaciones sobre este ser llegaran al istmo.

Un último aspecto que solamente señalo, ya que amerita una investigación más amplia (por el momento los datos son exiguos) es que en los estudios sobre los conjuros novohispanos se señala que este conjuro de santa Marta era practicado y transmitido solamente entre mujeres. ${ }^{82}$ ¿Las imágenes relacionadas con el conjuro en Ba'cuana fueron pintadas por mujeres o tuvieron la ayuda de algún hombre instruido? ¿Se trata de un arte realizado por mujeres?

79. Aunque la Inquisición no procesaba a personas indias desde 1572, y por tanto estos conjuros en principio corresponden a procesos inquisitoriales de españoles, mestizos o mulatos, en muchos de ellos aparecen personas que pueden considerarse indígenas, véase Campos Moreno, Oraciones, ensalmos y conjuros mágicos del archivo inquisitorial de la Nueva España (I600-I630), I03. Por otra parte, es difícil creer que dentro de los estratos bajos de la sociedad colonial, compuestos sobre todo por indios, mestizos, africanos y mulatos, no se produjeran estas transmisiones de ideas y creencias.

80. Machuca Gallegos, "Haremos Tehuantepec", 90.

8I Comunicación personal con Selene García Jiménez.

82. Quezada Ramírez, "Santa Marta en la tradición popular”, 228. 
$\mathrm{Al}$ respecto quisiera señalar dos cuestiones: en primer lugar, que en el área de Sola de Vega de habla zapoteca, al sur de los valles centrales de Oaxaca, a mediados del siglo XvII, existían varias especialistas rituales mujeres, aunque no sabemos si estaban alfabetizadas. ${ }^{83}$ Pero en otras partes en esa misma época, como en Morelos, sabemos de mujeres especialistas rituales alfabetizadas. ${ }^{84}$ Por otra parte, creo que es interesante recordar leyendas populares durante la colonia, como "La mulata, de Córdoba", en la que una mujer reconocida por sus conocimientos en curandería y conjuros, y que tenía pactos con el diablo, dibuja un barco en la pared de su celda mediante el cual consigue escapar de su prisión. ${ }^{85}$ Lo que quiero señalar es que en el imaginario popular de la época no era extrańo que una mujer pudiera dibujar o pintar, o utilizara este tipo de expresiones en sus prácticas rituales.

\section{Evolución del santuario: creación de nuevos paisajes simbólicos}

Ba’cuana fue un lugar sagrado de suma importancia en el Posclásico, constituyó el santuario que integró el nuevo paisaje simbólico que construyeron los zapotecos a su llegada al istmo un siglo y medio antes de la Conquista. Sin embargo, su historia no quedó trunca con la llegada de los españoles. Durante el virreinato continuó teniendo una gran importancia en el nuevo paisaje que estaban desarrollando los zapotecos, y tuvo una evolución interesante en su culto y en su percepción a lo largo de estos tres siglos, a juzgar por las intervenciones plásticas que se realizaron.

En un primer momento, en el siglo XvI, se observa que los zapotecos se encuentran en un proceso de asimilar la nueva cultura y las nuevas ideas religiosas a través de su tradición cultural, religiosa, artística y su sistema de comunicación. Por eso, están plasmando en su gran santuario la imagen por excelencia del cristianismo, la cruz, pero con su sistema de "escritura" pictográfico, y con sus convenciones de representación, simbólicas y estéticas. El intento de pintar las Arma Christi es un buen ejemplo de cómo se están aproximando al cristianismo por medio de los elementos que son más accesibles

83. Tavárez, Las guerras invisibles, 215. Es el área más cercana al istmo del que tenemos informaciones sobre mujeres especialistas rituales en la colonia.

84. Tavárez, Las guerras invisibles, 232.

85. Véase http://www.sanjuandeulua.inah.gob.mx/leyendas-de-la-fortaleza/la-mulata-decordoba), consultado en marzo de 2018. 
para ellos, esa especie de ideogramas cristianos sobre la Pasión de Cristo, pero que incluyen sus modificaciones. El guerrero muestra cómo todavía quieren transmitir sus mensajes y tradiciones, pero adoptando elementos de otra estética. Es interesante constatar también algo de cambios en la técnica, como en los pigmentos, aunque se nota que tienen elementos de continuidad con lo prehispánico. Destacan las nuevas soluciones plásticas como la reutilización de dos motivos prehispánicos para componer el motivo de la cruz como ofrenda. En esta etapa las imágenes pintadas muestran que la tradición prehispánica todavía predomina en la forma de acercarse al mundo y de aproximarse a las nuevas ideas europeas, también en el quehacer artístico y en la concepción de Ba'cuana como santuario.

En los dos siglos siguientes los cambios se aceleran. Se aprecia cómo en algunos aspectos aparentemente se va diluyendo la tradición prehispánica. La religión cristiana parece tomar el papel protagonista, y se adopta en general la tradición artística europea. Existen cambios en la técnica, aunque un aspecto que destaca es que se usan elementos iconográficos de tradición mesoamericana, como la flor en la cadera. Pero el hecho de pintar al Cristo en un gran santuario de origen prehispánico — un lugar sagrado zapoteco, situándolo en diálogo con las expresiones prehispánicas, en un rango similar- muestra que no se trata meramente de sustituir una tradición cultural por otra nueva, sino más bien de todo un proceso de construcción de una nueva forma de concebir el mundo y la existencia en el mismo por medio de una reelaboración y fusión de elementos selectivos de ambas tradiciones. Como se ha señalado en trabajos sobre arte rupestre colonial en otras latitudes, sus creadores, los zapotecos, son agentes activos en los procesos históricos y culturales. ${ }^{86}$ Están elaborando un nuevo paisaje cultural alrededor de Ba'cuana.

En este nuevo paisaje se enfatizan dos ámbitos diferentes del sitio, que se materializan en la diferencia de las imágenes. En las imágenes del Posclásico no se aprecian grandes discrepancias entre la iconografía de las dos rocas, aunque sí se han reconocido algunas diferencias: en la peña-parada aparece un personaje con un disco solar, inexistente en la peña-cueva (véase fig. 9). En el siglo XVI, quizás se abunda en esta diferencia ya que se representa un guerrero,

86. May, Domingo y Taçon, "Arte rupestre de contacto", 88; Françoise Fauconnier, "Arte rupestre en el área del río San Juan del Oro (sureste boliviano). Continuidad y rupturas". En La vitalidad de las voces indígenas: arte rupestre del contacto y en sociedades coloniales, Fernando Berrojalbiz, ed. (México-Instituto de Investigaciones Estéticas, UNAM, 20I5), 387-4I4. 
motivo que no se plasma en la otra roca. En las imágenes de los siglos XVII y xviII se observa una división entre un ámbito abierto, público, luminoso, del Dios salvador, de la fertilidad y protección para todos, el Cristo crucificado (los paneles de la peña-parada, expuestos al sol), y otro ámbito donde se aproximan simbolismos y significados del interior de la montańa y del inframundo prehispánico con el cubículo del diablo cristiano, la "cueva" de la peña-cueva. Llama la atención que se utilizaron pigmentos muy similares para los motivos de estos dos ámbitos. En la colonia este santuario reúne y representa los diferentes aspectos y ámbitos del nuevo orden del universo que estaban desarrollando los zapotecos en el istmo.

Normalmente, cuando se habla de idolatrías en pueblos indígenas en la colonia, se piensa en indios realizando culto o rituales de tradición prehispánica con algunos elementos mezclados de la religión cristiana. En la peńa-parada de Ba'cuana existe la evidencia de cultos o prácticas de conjuros relacionados con la parte malvada de una santa católica y con el diablo, es decir, con la parte no ortodoxa o herética del cristianismo. En este caso no tengo la certeza absoluta de que se trataba de indígenas, pero la probabilidad es muy grande, por el contexto histórico, y especialmente por pintarse en un lugar sagrado de origen prehispánico y por ese afán de vincularse con las imágenes antiguas. Esto muestra la capacidad de agencia de grupos de indígenas en la colonia que pueden incluso apropiarse de visiones alternas prohibidas de la religión cristiana y reelaborarlas a su manera, para reactualizar sus lugares sagrados. Para el caso de Oaxaca, creo que es la primera vez que se descubren conjuros heréticos y diabólicos cristianos realizados por parte de una población indígena. Además, está la posibilidad de que las expresiones relacionadas con estos últimos hayan sido realizadas por mujeres.

Todo lo anterior refuerza la idea de esa construcción de una cultura inédita, con una fusión o amalgama de elementos de dos tradiciones de forma asimétrica, pero construyendo algo diferente: un nuevo paisaje sagrado. Sin embargo, hay cierta continuidad en algunos elementos, como la importancia de Ba'cuana como santuario zapoteca en ese novedoso paisaje durante el virreinato ya que es el único sitio de arte rupestre en la región donde se han observado imágenes coloniales, ${ }^{87}$ de un total de más de 35 sitios descubiertos en la región. En otras áreas del mundo donde se han estudiado expresiones rupestres coloniales se ha constatado que las poblaciones indígenas construyen un paisaje poscontacto

87. En otro sitio, Zopiloapam, recientemente se han descubierto dos posibles motivos coloniales. 
DOI: https://doi.org/10.22201/iie.18703062e.2020.116.2718

articulado mediante la celebración de ceremonias en diversos lugares y la señalización del nuevo territorio por medio del arte rupestre. Estas investigaciones concluyen que esa creación constituye su respuesta activa y su mejor estrategia de lucha y resistencia cultural contra la colonización europea ${ }^{88}$ Creo que algo similar ocurrió con los zapotecos del istmo después de la Conquista y su particular creación o reformulación de su paisaje sagrado. \$

88. May, Domingo y Taçon, "Arte rupestre de contacto", 88.

N.B. Este trabajo se pudo realizar gracias al apoyo del Programa papit de la Universidad Nacional Autónoma de México, al proyecto: Arte Rupestre de Durango y Oaxaca: una perspectiva comparativa (IN402717). El análisis de los pigmentos se realizó gracias al apoyo del Programa PAPIIT al proyecto: El arte rupestre en la reformulación de los paisajes simbólicos indígenas en la colonia: un estudio comparativo de Durango y Oaxaca (IN4O27I4), y al Laboratorio Nacional de Ciencias para la Investigación y Conservación del Patrimonio Cultural (LANCIC) a través de los proyectos financiados Conacyt LN 2326r9, LN 279740 y LN 293904 y el apoyo parcial de los proyecos Conacyt CB239609 y PAPIIT INII2OI8.

Agradezco la ayuda y los comentarios de las siguientes personas que fueron de gran importancia para la realización de este trabajo: Robert Markens, José Leonardo López Zárate, Iván Escamilla, Franziska Neff, Isela Peña, Gustavo Curiel, Saeko Yanagisawa, Gonzalo Sánchez Santiago y Marie-Areti Hers. 